\title{
Summary of Property Measurements from CST Glass Study
}

by

T. B. Edwards

Westinghouse Savannah River Company

Savannah River Site

Aiken, South Carolina 29808

J. R. Harbour

R. J. Workman

This paper was prepared in connection with work done under the above contract number with the U.S. Department of Energy. By acceptance of this paper, the publisher and/or recipient acknowledges the U.S. Government's right to retain a nonexclusive, royalty-free license in and to any copyright covering this paper, along with the right to reproduce and to authorize others to reproduce all or part of the copyrighted paper. 
WSRC-TR-99-00384

Revision 0

Keywords: Coupled Operation, DWPF, Liquidus Temperature, PCCS, PCT,

Salt Dispósition, Viscosity

Retention Time: Permanent

\section{Summary of Property Measurements FROM CST GLASS STUDY (U)}

T. B. Edwards

J. R. Harbour

R. J. Workman

Westinghouse Savannah River Company

Savannah River Technology Center Aiken, SC 29808

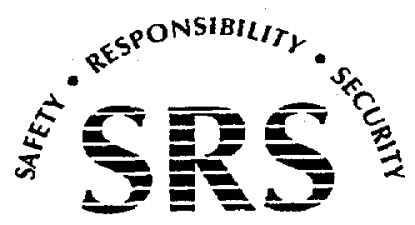

SAVANNAH RIVER SITE

PREPARED FOR THE U.S. DEPARTMENT OF ENERGY UNDER CONTRACT NO. DE-AC09-96SR18500 
WSRC-TR-99-00384

Revision 0

\section{DISCLAIMER}

This report was prepared as an account of work sponsored by an agency of the United States Government. Neither the United States Government nor any agency thereof, nor any of their employees, makes any warranty, express or implied, or assumes any legal liability or responsibility for the accuracy, completeness, or usefulness of any information, apparatus, product, or process disclosed, or represents that its use would not infringe privately owned rights. Reference herein to any specific commercial product, process, or service by trade name, trademark, manufacturer, or otherwise does not necessarily constitute or imply its endorsement, recommendation, or favoring by the United States Government or any agency thereof. The views and opinions of authors expressed herein do not necessarily state or reflect those of the United States Government or any agency thereof.

This report has been reproduced directly from the best available copy.

Available to DOE and DOE contractors from the Office of Scientific and Technical Information, P.O. Box 62, Oak Ridge, TN 37831; prices available from (615) 576-8401.

Available to the public from the National Technical Information Service, U.S. Department of Commerce; 5285 Port Royal Road, Springfield, VA 22161. 


\section{DISCLAIMER}

Portions of this document may be illegible in electronic image products. Images are produced from the best available original document. 


\section{Summary of Property Measurements from CST Glass Study (U)}

October 4, 1999

Document Approvals

\section{Homas \& cenards}

T. B. Edwards, Author

Statistical Consulting Section

\section{Gtim r tantrue}

J. R. Harbour, Author

Imm66ilization Technology Section

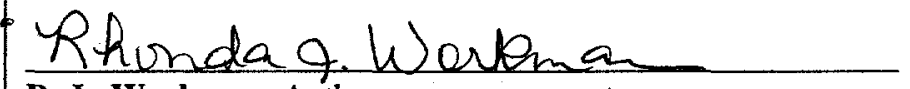

R. J. Workman, Author

Immobilization Technology Section

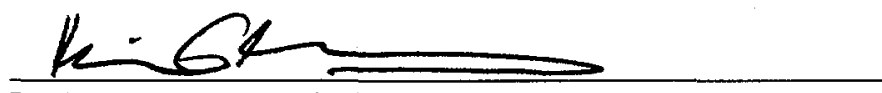

K. G. Brown, Technical Review Immobilization Technology Section

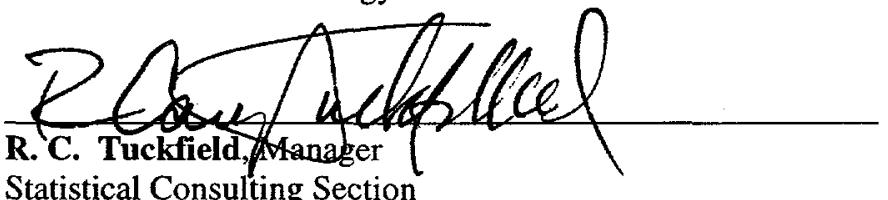

Statistical Consulting Section

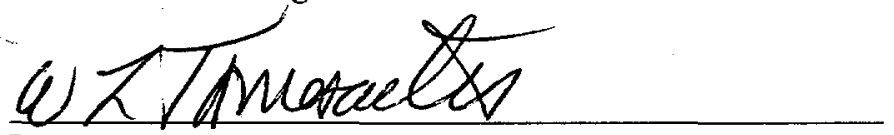

W. L. Tamosaitis, Manager

Waste Processing Technology Section

\section{Ew thetsphato}

E. W. Holtzscheiter, Manager

Immobilization Technology Section

Authorized Derivative Classifier

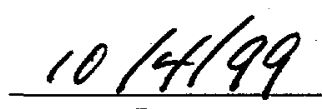

Date
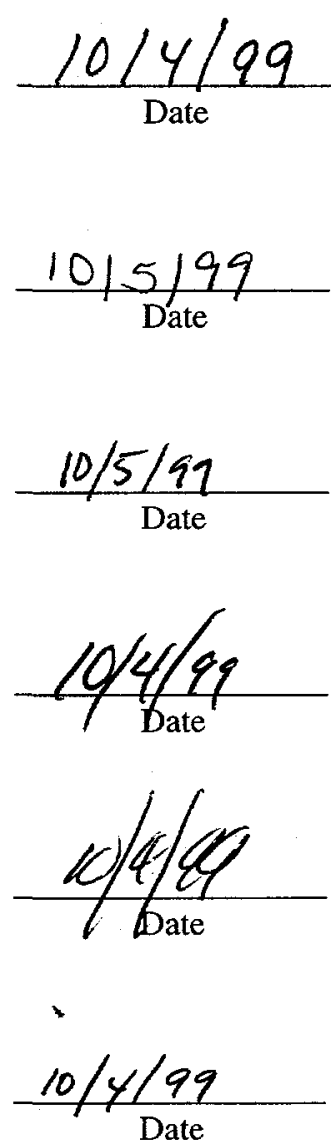

$1-\operatorname{con} 5$

J. 6. Carter, Manager, HLW Process Engineering

Signature Signifies SatisApctory Completion of CST Glass Study

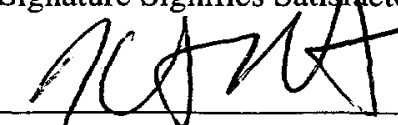

K. J. Rueter, Director, Salt Disposition Engineering

Signature Signifies Satisfactory Completion of CST Glass Study
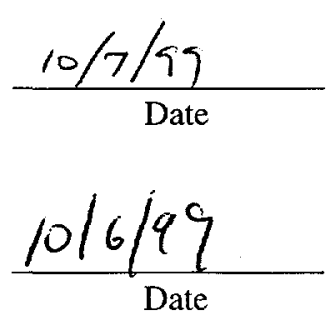
WSRC-TR-99-00384

Revision 0

This page intentionally left blank. 


\section{TABLE OF CONTENTS}

Summary and Conclusions ........................................... 1

Introduction ..........................................................

Results and Discussion .............................................. 4

Target and Measured Chemical Compositions ...................... 4

PCT Results ..................................................... 5

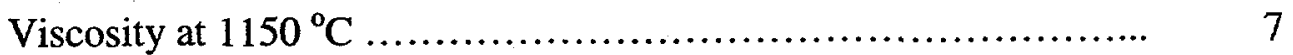

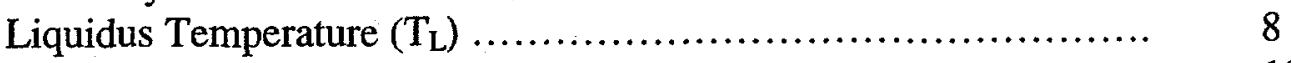

Surface Crystallization ..................................... 10

Phase Separation ............................................ 11

Conclusions ............................................................ 13

References .............................................................. 15

Appendix: Supplemental Tables and Exhibits ......................... 17 
WSRC-TR-99-00384

Revision 0

This page intentionally left blank. 


\section{SUMMARY AND CONCLUSIONS}

This report is a modified version of WSRC-TR-99-00324, Revision 0. All data related to the composition of Crystalline Silicotitanate (CST) and to the proprietary frit (the glass formers) used during this study have been removed for this version. As a consequence of the need to remove confidential and proprietary information, this report also does not contain the tables of detailed target and measured glass compositions provided in WSRC-TR-99-00324. The report does, however, provide the full details of the glass property measurements generated as part of this study and relates these to glass composition considered in the more general components of sludge, CST, Monosodiumtitanate (MST), and frit.

This report provides a summary of the results obtained for a limited variability study for glasses containing Crystalline Silicotitanate (CST), Monosodiumtitanate (MST), and either simulated Purex or HM sludge. Twenty-two glasses containing Purex sludge and three glasses containing HM sludge were fabricated and tested. The fabricated glasses were tested for durability using the 7-day Product Consistency Test (PCT) and characterized by measuring the viscosity at $1150^{\circ} \mathrm{C}$ and by determining an approximate, bounding liquidus temperature. The current models used by Defense Waste Processing Facility (DWPF) for predicting durability, viscosity, and liquidus temperature were applied to all 25 glasses. The goal of this work was to identify any major problems from a glass perspective, within the scope of this effort, which could potentially preclude the use of CST at DWPF.

The selection of Purex sludge for this study was based on the knowledge that this sludge type has historically been the most difficult sludge to incorporate into glass. Depleted uranium was introduced into the simulated Purex sludge to better represent the uranium content $(\sim 9 \mathrm{wt} \%$ oxide) of actual sludge.

One of the major elements of concern for this study was titanium, which the DWPF currently restricts to a value of less than $1 \mathrm{wt} \% \mathrm{TiO}_{2}$ in glass. The introduction of CST and MST in this study results in $\mathrm{TiO}_{2}$ levels in the glasses that significantly exceed the current limit. Furthermore, CST introduces $\mathrm{x}_{1}$, a proprietary component of CST with an unknown impact on glass quality and processing properties and higher levels of $x_{2}$ (a second proprietary component of CST) than previously studied.

The "frit" (for this study, the glass formers were added as powders rather than a frit) composition was one of two optimized formulations selected from previous work at SRTC. This particular "frit" formulation is part of a current patent application.

As part of this study, product and property model predictions were made using targeted, measured, and bias-corrected measured compositions of the glasses. It was demonstrated that the results were essentially insensitive to the type of composition used in these models. This provides evidence that the glasses produced were close to the targeted compositions, and that the analytical measurements were of high quality.

Glass Durability. All 25 glasses were very durable as measured by the PCT. The PCT values clustered within the interval from 0.64 to $0.91 \mathrm{~g} / \mathrm{L}$ for boron for all of the Purex glasses except one and ranged from 0.37 to $0.43 \mathrm{~g} / \mathrm{L}$ for boron for the $\mathrm{HM}$ glasses. The values for the other elements were similar. For comparison, the reference Environmental Assessment (EA) glass has a boron rate of 16.7 $\mathrm{g} / \mathrm{L}$. A remarkable finding from this study was the highly clustered nature of the results. The 22 Purex-loaded glasses clustered tightly in one region, whereas the HM glasses clustered at an even lower value for boron release.

Model Prediction of Durability. DWPF's Product Composition Control System (PCCS) durability model predicted values for boron release that were generally greater than the upper $95 \%$ prediction limit of the model. This type of behavior has been observed before for a range of glasses predicted to be very durable. The highly clustered nature of the results suggests that model revisions could be made to ensure predictability of the glasses. 
Homogeneity. The DWPF durability model was developed for glasses that are not phase separated (amorphous), and the use of this model is controlled, in part, through the application of a homogeneity discriminator or constraint. The majority of the CST glasses failed this homogeneity constraint (i.e., they are predicted to be phase separated) even though they demonstrated very good durabilities. Good durability does not ensure the lack of phase separation. However, the current, DWPF homogeneity - constraint was not developed for glasses within the compositional region defined for these 25 glasses. The results from this study reveal that the measured durabilities are not correlated to the values of this homogeneity constraint for these glasses. This is evident from the tightly clustered PCT results.

Liquidus: For this study, the liquidus temperature was bounded by performing 24-hour isothermal holds (as required) for the glass melts at $900^{\circ} \mathrm{C}, 950^{\circ} \mathrm{C}, 1000^{\circ} \mathrm{C}$, and $1050^{\circ} \mathrm{C}$. X-ray diffraction (XRD) was used to detect crystallization, in this case Trevorite. For the 22 wt\% Purex glasses, no crystals were detected in the bulk at $900^{\circ} \mathrm{C}$ or at the top surface of the glasses. For the $26 \mathrm{wt} \%$ Purex glasses, only two of the six glasses had bulk crystals after 24 hours at $900^{\circ} \mathrm{C}$, and crystallization was no longer evident after the 24 hour hold at $950^{\circ} \mathrm{C}$. For the $30 \mathrm{wt} \%$ Purex glasses, crystals were evident at higher temperatures but below the XRD detection limit at $1000^{\circ} \mathrm{C}$. Given the fact that liquidus temperatures were only bounded, the $30 \mathrm{wt} \%$ loading of Purex may be near or at the edge of acceptability for liquidus. Surface crystallization was evident on top of the glass surface near the glass-crucible interface after some of the heat treatments. This crystallization was not considered as evidence in the determination of the approximate liquidus temperature. For HM glasses, no crystals were detected in the bulk or on the surface after 24 hours at $900^{\circ} \mathrm{C}$.

Viscosity. The melt viscosity for many of these glasses was measured and the results reported at $1150^{\circ} \mathrm{C}$ (nominal temperature of the glass within the DWPF melter). For the Purex containing glasses, all viscosities were well within the DWPF range of 20 to 100 poise. The viscosity model in general, overpredicted the measured viscosities. This is not surprising given the fact that the model was not developed for glasses incorporating CST elements. On the other hand, the HM sludge-containing glasses had, as predicted, viscosities at $1150^{\circ} \mathrm{C}(\sim 160$ poise $)$ that were far above the 100 poise limit. Thus, the HM sludge-containing glasses fabricated for this study are not acceptable for processing in the DWPF. Although no Blend sludge glasses were fabricated, viscosity predictions for these glasses suggest that viscosity values may be close to 100 poise, or the upper limit for DWPF operations.

Limitations. All of the conclusions are provided based on the scope of the current work. One limitation of this scope, based upon schedule and budget, was the absence of any investigation of kinetic effects. Thus, one cannot rule out that amorphous phase separation occurs with centerline cooling, for example, and this could have a deleterious effect on the durability of the glass. A second limitation was the restriction on independent variation of chemical constituents. In a major variability study, ranges are established for each element, and a statistically designed set of glasses identified which not only covers a larger region of compositional space, but also provides the potential for revealing (or confirming) relationships between the properties and the glass compositions. A third limitation was that only approximate and bounding measurements of the liquidus temperatures were made. A fourth limitation was that a thorough search (beyond scanning electron microscopy) for phase separation was not conducted. This type of investigation requires considerable efforts using transmission electron microscopy (TEM) and/or other high-resolution techniques. Finally, although the strategy was that HM and Purex containing glasses would cover the extremes, no Blend sludge (a combination of the HM and Purex sludges) glasses were fabricated to verify this. 


\section{INTRODUCTION}

One of the Alternative Salt Disposition Flowsheets being considered would require that the Defense Waste Processing Facility (DWPF) vitrify a coupled feed containing High Level Waste (HLW) and Crystalline Silicotitanate (CST). A Technical Task Request (TTR) [1] was received by the Savannah River Technology Center (SRTC) requesting that a glass variability study be conducted to explore the processability and product quality of the glass composition region for this alternative to the In-Tank Precipitation (ITP) Process. A Task Technical and Quality Assurance (TT\&QA) plan [2] was issued by SRTC in response to the TTR. The objective of this task was to obtain information on the feasibility of incorporating anticipated levels of CST into DWPF glass with and without doubling the nominal levels of monosodiumtitanate (MST). The study progressed through four phases of investigation, the detailed results of which have each been issued in technical reports (see references [3] through [6]).

A final report, "Summary of Results for CST Glass Study: Composition and Property Measurements," WSRC-TR-99-00324, Revision 0, was prepared to consolidate the results of these four phases and to provide overall conclusions. That final report (as well as each of the references [3] through [6]) contains confidential and proprietary information. The purpose of this report is to provide a summary of these results that does not contain such information. Thus, all data related to the composition of CST and to the proprietary frit (the glass formers) used during this study have been removed for this version. This report also does not contain the tables of detailed target and measured glass compositions provided in WSRC-TR-99-00324. The report does, however, provide the full details of the glass property measurements generated as part of this study and relates these to glass composition considered in the more general components of sludge, CST, MST, and frit.

Table 1 provides a general overview of the glass compositions that were batched, fabricated, and tested as part of this study. The glasses were selected from a set of candidate glasses that involved three sludge types: Purex, HM, and Blend; covered sludge loadings (in the glass) of 22, 26, and 30 oxide weight percent (wt\%); utilized CST loadings (in the glass) of 3,6, and 9 oxide wt \%; and included MST concentrations (in the glass) at 1.25 and $2.5 \mathrm{wt} \%$. For each composition, the remainder of the glass consisted of a proprietary frit. The goal of using Purex sludge as the major sludge type with only a few glasses containing HM was realized. However, no glasses were fabricated using the Blend sludge (a sludge representing the combination of $\mathrm{HM}$ and Purex).

Table 1: General Compositions of the CST Glasses

\begin{tabular}{|ccccccc|}
\hline Phase & Glass ID & Sludge Type & Sludge Loading & CST & MST & Proprietary Frit \\
1 & cst07 & Purex & $26 \%$ & $3 \%$ & $1.25 \%$ & $69.75 \%$ \\
1 & cst08 & Purex & $26 \%$ & $6 \%$ & $1.25 \%$ & $66.75 \%$ \\
1 & $\operatorname{cst09}$ & Purex & $26 \%$ & $9 \%$ & $1.25 \%$ & $63.75 \%$ \\
1 & $\operatorname{cst10}$ & Purex & $26 \%$ & $3 \%$ & $2.5 \%$ & $68.50 \%$ \\
1 & $\operatorname{cst11}$ & Purex & $26 \%$ & $6 \%$ & $2.5 \%$ & $65.50 \%$ \\
1 & $\operatorname{cst12}$ & Purex & $26 \%$ & $9 \%$ & $2.5 \%$ & $62.50 \%$ \\
2 & $\operatorname{cst13}$ & Purex & $30 \%$ & $3 \%$ & $1.25 \%$ & $65.75 \%$ \\
2 & $\operatorname{cst14}$ & Purex & $30 \%$ & $6 \%$ & $1.25 \%$ & $62.75 \%$ \\
2 & $\operatorname{cst15}$ & Purex & $30 \%$ & $9 \%$ & $1.25 \%$ & $59.75 \%$ \\
2 & $\operatorname{cst16}$ & Purex & $30 \%$ & $3 \%$ & $2.5 \%$ & $64.50 \%$ \\
2 & $\operatorname{cst17}$ & Purex & $30 \%$ & $6 \%$ & $2.5 \%$ & $61.50 \%$ \\
2 & $\operatorname{cst18}$ & Purex & $30 \%$ & $9 \%$ & $2.5 \%$ & $58.50 \%$ \\
3 & $\operatorname{cst01}$ & Purex & $22 \%$ & $3 \%$ & $1.25 \%$ & $73.75 \%$ \\
3 & $\operatorname{cst02}$ & Purex & $22 \%$ & $6 \%$ & $1.25 \%$ & $70.75 \%$ \\
3 & $\operatorname{cst03}$ & Purex & $22 \%$ & $9 \%$ & $1.25 \%$ & $67.75 \%$ \\
3 & $\operatorname{cst04}$ & Purex & $22 \%$ & $3 \%$ & $2.5 \%$ & $72.50 \%$ \\
3 & $\operatorname{cst05}$ & Purex & $22 \%$ & $6 \%$ & $2.5 \%$ & $69.50 \%$ \\
3 & $\operatorname{cst06}$ & Purex & $22 \%$ & $9 \%$ & $2.5 \%$ & $66.50 \%$ \\
4 & $\operatorname{cst11c}$ & Purex & $26 \%$ & $6 \%$ & $2.5 \%$ & $65.50 \%$ \\
4 & $\operatorname{cst12c}$ & Purex & $26 \%$ & $9 \%$ & $2.5 \%$ & $62.50 \%$ \\
4 & $\operatorname{cst17c}$ & Purex & $30 \%$ & $6 \%$ & $2.5 \%$ & $61.50 \%$ \\
4 & $\operatorname{cst18c}$ & Purex & $30 \%$ & $9 \%$ & $2.5 \%$ & $58.50 \%$ \\
4 & $\operatorname{cst20}$ & HM & $22 \%$ & $6 \%$ & $1.25 \%$ & $70.75 \%$ \\
4 & $\operatorname{cst26}$ & HM & $26 \%$ & $6 \%$ & $1.25 \%$ & $66.75 \%$ \\
4 & $\operatorname{cst32}$ & HM & $30 \%$ & $6 \%$ & $1.25 \%$ & $62.75 \%$ \\
\hline
\end{tabular}


The primary property of interest in this study was the durability (as measured by the 7-day Product Consistency Test, PCT [7]) of the test glasses. The PCT is the recognized standard for determining the durability of vitrified HLW, and the Environmental Assessment (EA) glass is the reference standard for assessing acceptable durability determined using the PCT. ${ }^{1}$ The measurement of durability was conducted to the specifications of the PCT Method A of ASTM C1285 for each and every glass of this

- study. (See the analytical plan [8] and the individual phase reports, [3] through [6], for details.)

Processing properties of interest for these glasses included viscosity at $1150^{\circ} \mathrm{C}$ and liquidus temperature. Methods used to complete these two types of measurements did not follow a standard ASTM procedure. However, viscosity was measured at SRTC using a Harrop viscometer [9] that has yielded good results [10]. The standard ASTM procedure for measuring liquidus temperature, $T_{L}$, uses a gradient furnace. Since no such capability exists at SRTC, it was beyond the scope of this study to pursue this process for obtaining $T_{L}$ measurements. To gain insight into this important processablility property for the CST glasses, an attempt was made to obtain an upper bound on the $T_{\mathbf{L}}$ 's using isothermal holds at 900,950,1000, and $1050^{\circ} \mathrm{C}$ and (non-quantitative) XRD evaluations (with a sensitivity of $\sim 0.7$ to $1 \mathrm{wt} \%$ for crystalline Trevorite in the glass). The results from these measurements are presented in this final report (the reports for the individual phases ([3], [4], [5], and [6]) provide greater detail).

In the report for each phase of this study, comparisons were provided between

- the measured and target compositions of the test glasses and

- the property measurements and their predictions derived from models that are used by the Defense Waste Processing Facility (DWPF) as part of its Product Composition Control System (PCCS). These models relate processability and product quality (e.g., viscosity, $\mathrm{T}_{\mathrm{L}}$, and durability) to glass composition.

These comparisons were consolidated and discussed in the confidential and proprietary final report WSRC-TR-99-00324. No detailed data regarding the compositions (target or measured) are provided in the discussion that follows but compositions are addressed in a more general manner. The discussion of glass property measurements generated during this CST glass study presented in this report is identical to that appearing in WSRC-TR-99-00324.

\section{RESULTS AND DISCUSSION}

The composition and property measurements of the glasses comprising the four phases of the CST study were conducted in parallel with glasses from the corresponding phases of the other ITP replacement alternative, Small Tank TPB Precipitation. This small tank study was designated as the PHA (Precipitate Hydrolysis Aqueous) glass study (references [11], [12], [13], and [14] provide the reports for the four phases of this study). Conducting the two studies in parallel helped to ensure that the CST and PHA glasses were fabricated, characterized, and analyzed under very similar conditions. For a full description of the analytical plans or of the review of the measurement data, see the individual reports for the phases of the CST study [3]-[6].

\section{Target and Measured Chemical Compositions}

Measurements of the compositions of the test glasses were conducted by the SRTC-Mobile Laboratory (SRTC-ML) and by the Analytical Development Section (ADS) of SRTC. Standards were included with the test glasses and bias-corrections were conducted for many of these measurements. Details are provided in the individual phase reports. In most instances, the property predictions were essentially insensitive to the way the compositions of these glasses were represented (i.e., whether by targeted, measured, or bias-corrected measurements). In certain instances discrepancies between target and

1 For a glass to demonstrate acceptable durability its PCT leach rate must be 2-sigma better than the PCT leach rate of the EA glass. 
measured compositions were investigated to gain insight into the batching and/or targeting processes used during the phases of this study.

One such discrepancy, discovered during Phases 1 and 2, was the factor used to account for the MST components in the final glass product. This problem revealed itself in compositions that failed to meet the desired $\mathrm{TiO}_{2}$ targets and led to a re-evaluation of MST, a source of $\mathrm{TiO}_{2}$ in the glass. A subsequent

- analysis of MST revealed a larger than expected moisture content. The problem was corrected for Phase 3, and additional glasses (cst11c, cst12c, cst17c, and cst18c designated in Phase 4 with a "c" suffix in Table 1) from the first two phases were introduced into Phase 4. The $\mathrm{TiO}_{2}$ levels were met for Phases 3 and 4.

The sum of oxides for all of these glasses fell within the interval of 95 to $105 \mathrm{wt} \%$, a measure of the quality of the analytical results. For the composition of cst16, the boron and sodium concentrations of this glass stand out as being higher than their respective targets.

\section{PCT Results}

All of the CST glasses, after being batched and fabricated, were subjected to the 7-day Product Consistency Test (PCT) as an assessment of their durabilities [7]. More specifically, Method A of PCT (ASTM C1285) was used for these measurements. Durability is the critical product quality metric for vitrified nuclear waste. The PCT responses (for four elements: boron, silicon, sodium, and lithium) were normalized to the units of grams-per-liter $(\mathrm{g} / \mathrm{L})$ using the measured, measured biascorrected, and target compositions. In addition to the CST test glasses, the Environmental Assessment (EA) glass and the ARM glass were subjected to the PCT. The individual phase reports provide the details of the analytical plan and resulting data supporting these tests. The results from these tests are summarized in Table A.1 of the Appendix.

As seen in Table A.1, the durabilities for the CST glasses are considerably better than those of the EA glass. Figure 1 provides an opportunity for a closer look at these results using measured and biascorrected compositions. Figure 1 is a plot of the DWPF model that relates the common logarithm of the normalized PCT (in this case for B) to a linear function of a free energy of hydration term $\left(\Delta G_{p}\right.$, $\mathrm{kcal} / 100 \mathrm{~g}$ glass) derived from the glass (measured and bias-corrected) compositions [15]. Prediction limits (at 95\% confidence) for individual PCT results are also plotted around this linear fit. The PCT results for EA (shown as a diamond), ARM (shown as a "z"), and the CST glasses (shown as open squares) are presented on this plot. Note that the CST results reveal acceptable PCT values although they are not well predicted by the current DWPF durability model. (Almost all of the CST values are slightly higher than the upper prediction limit.) Figure 2 provides a plot of the boron results based upon target compositions, which shows a similar pattern of behavior. Exhibit A.1 in the Appendix provides similar plots of the CST durability measurements versus the DWPF durability models for B, $\mathrm{Si}, \mathrm{Na}$, and $\mathrm{Li}$. The behaviors seen in the plots for $\mathrm{Si}, \mathrm{Na}$, and $\mathrm{Li}$ are similar to that demonstrated by the $\mathrm{B}$ results: acceptable but unpredictable durabilities. 
Figure 1.

$\log \mathrm{NL}(\mathrm{B})(\mathrm{g} / \mathrm{L})$ By del Gp

(Using Measured \& Bias-corrected CST Glass Compositions

\& EA and ARM reference compositions)

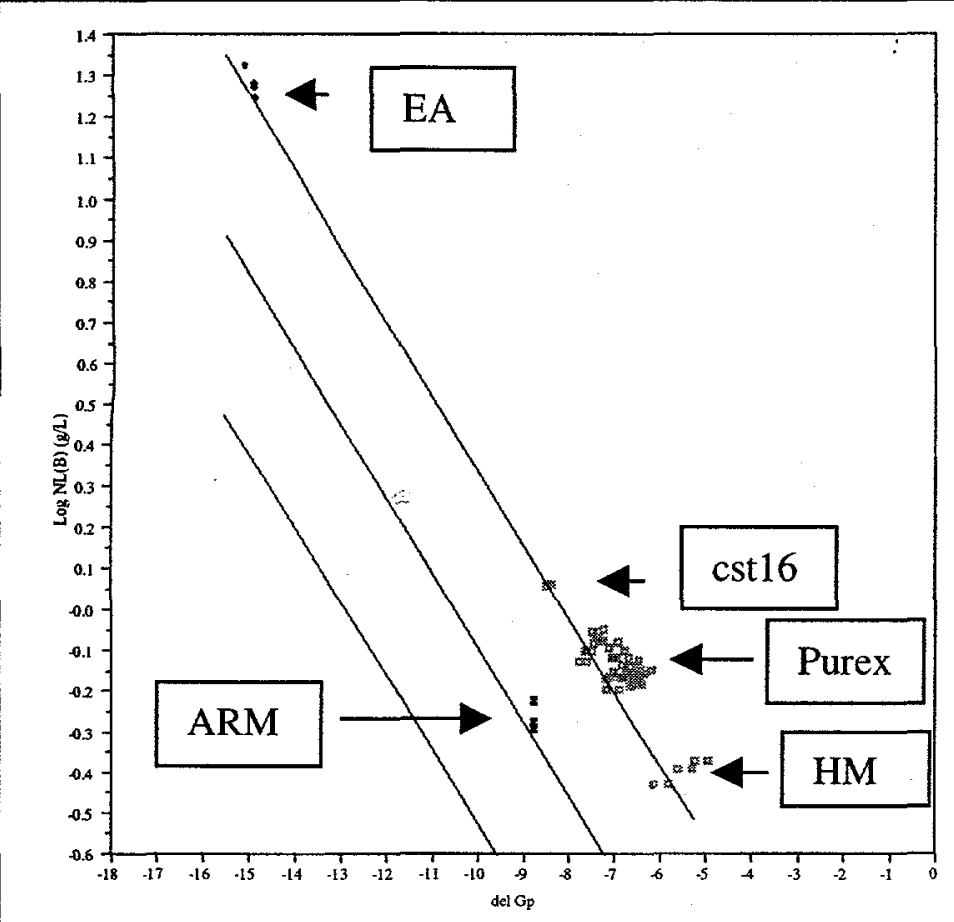

Figure 2.

$\log N L(B)(g / L)$ By del Gp (Using target compositions for the CST glasses

\& EA and ARM reference compositions)

Figures 1 and 2 as well as those provided in the Appendix reveal that the PCT results for these CST glasses are consistently underpredicted by the current DWPF durability models. Possible reasons for this behavior include

(1) Species such as element $x_{1}$ of CST not being adequately addressed by the current durability models;

(2) The CST glasses may be phase separated --- thus, violating one of the prerequisites for the use of the durability models.

(3) A tendency for the durability models to underpredict glasses with $\Delta \mathrm{G}_{p}$ values greater than $-8.5 \mathrm{kcal} / 100 \mathrm{~g}$ glass. ${ }^{2}$. As seen ${ }^{*}$ in Figures 1 and 2 , the $\Delta G_{p}$ values for these CST glasses are greater than $-8 \mathrm{kcal} / 100 \mathrm{~g}$ glass regardless of how the $\Delta G_{p}$ values are determined; i.e., from target, measured, or bias-corrected compositions.

2 See Figure 59a of WSRC-TR-93-672, Rev. 1 [15], which shows that the fitted model for boron consistently underpredicts all of those glasses used to develop the model for which the $\Delta G_{p}$ value is greater than $-8.5 \mathrm{kcal} / 100 \mathrm{~g}$ glass. 


\section{Viscosity at $1150^{\circ} \mathrm{C}$}

Viscosity measurements were made on these six Phase 1 CST glasses at SRTC using a Harrop, hightemperature viscometer [9]. The viscosity (in Poise) of each of these glasses at $1150^{\circ} \mathrm{C}$ is to be estimated from a Fulcher equation fitted to a set of viscosity measurements taken over an appropriate range of temperatures. The functional form of the (three-parameter) Fulcher equation (expressed in

- Poise) used to fit these data is given by equation (1):

$$
\ln \hat{\eta}=A+\frac{B}{(T-C)}
$$

where $\mathrm{A}, \mathrm{B}$, and $\mathrm{C}$ represent the parameters of the model that were determined from the available measurements (represented by $\eta$, expressed in Poise) at various temperatures (represented by $T$ ). The fitted model was then used to predict the viscosity of the given glass at $1150^{\circ} \mathrm{C}$.

Although no definitive error analysis has been completed on the use of the Harrop viscometer, SRTC has conducted several sets of viscosity measurements using this viscometer with good results [10]. Viscosity measurements were not conducted for all of these CST glasses. Table 2 provides the results that were obtained as part of this study.

Table 2: Viscosity Results (in Poise) By Glass ID for the CST Glasses

\begin{tabular}{|c|c|c|c|c|}
\hline Glass ID & $\begin{array}{c}\text { Viscosity } \\
\text { (Poise) } \\
@ 1150^{\circ} \mathrm{C}\end{array}$ & $\begin{array}{c}\text { Predicted } \\
\text { (measured } \\
\text { composition) }\end{array}$ & $\begin{array}{c}\text { Predicted } \\
\text { (bias-corrected } \\
\text { composition) }\end{array}$ & $\begin{array}{c}\text { Predicted } \\
\text { (target } \\
\text { composition) }\end{array}$ \\
\hline csto1 & 70.5 & 83.7 & 91.5 & 91.6 \\
\hline $\operatorname{cst} 02$ & Not Measured & 81.0 & 88.7 & 90.6 \\
\hline cst03 & Not Measured & 81.0 & 88.7 & 89.5 \\
\hline cst04 & Not Measured & 77.1 & 84.6 & 88.9 \\
\hline cst05 & Not Measured & 79.4 & 87.0 & 87.8 \\
\hline $\operatorname{cst} 06$ & 63.0 & 78.2 & 85.7 & 86.7 \\
\hline cst07 & 72.1 & 84.0 & 84.8 & 78.6 \\
\hline cst08 & 64.1 & 94.0 & 94.9 & 77.3 \\
\hline $\operatorname{cst09}$ & 56.8 & 84.1 & 85.0 & 75.9 \\
\hline cst10 & 62.6 & 88.3 & 89.5 & 76.0 \\
\hline $\operatorname{cst1} 1$ & 54.5 & 77.7 & 78.7 & 74.6 \\
\hline $\operatorname{cst} 11 \mathrm{c}$ & Not Measured & 63.7 & 72.6 & 74.6 \\
\hline $\operatorname{cst} 12$ & 50.0 & 79.4 & 80.1 & 73.2 \\
\hline $\operatorname{cst} 12 c$ & 51.4 & 68.5 & 78.6 & 73.2 \\
\hline cst13 & Not Measured & 62.2 & 69.7 & 66.3 \\
\hline $\operatorname{cst} 14$ & 51.9 & 64.6 & 69.8 & 64.8 \\
\hline $\operatorname{cst1} 5$ & 53.3 & 65.5 & 74.0 & 63.2 \\
\hline cst16 & Not Measured & 44.0 & 47.4 & 63.8 \\
\hline cst17 & Not Measured & 67.5 & 72.8 & 62.2 \\
\hline $\operatorname{cst} 17 \mathrm{c}$ & Not Measured & 60.1 & 69.2 & 62.2 \\
\hline $\operatorname{cst} 18$ & Not Measured & 58.6 & 63.3 & 60.6 \\
\hline $\operatorname{cst} 18 c$ & Not Measured & 54.9 & 63.3 & 60.6 \\
\hline cst20 & 158.8 & 134.5 & 149.0 & 164.5 \\
\hline cst26 & 154.5 & 144.4 & 160.7 & 162.8 \\
\hline cst32 & 160.1 & 150.2 & 167.9 & 161.0 \\
\hline
\end{tabular}

Figure 3 provides a plot of the measured viscosities versus the viscosities predicted from the DWPF model using target, measured, and bias-corrected compositions. A 45-degree (diagonal) line is also shown for reference. 
Figure 3: Viscosity Measurements versus Property Predictions

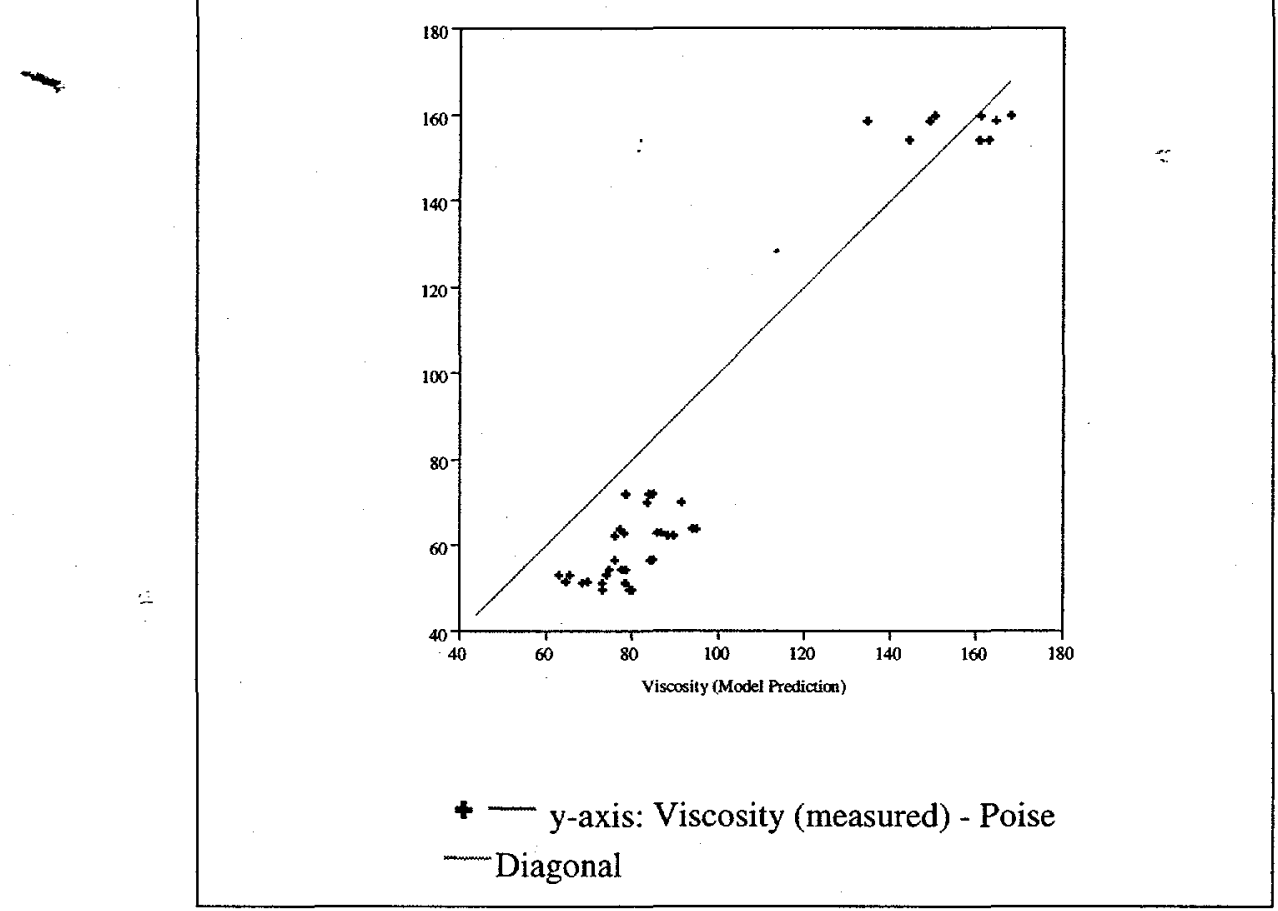

The melt viscosities at $1150^{\circ} \mathrm{C}$ for all CST glasses fabricated using Purex are all well within the operating range for DWPF (20 to 100 Poise). Therefore, processing these glasses in the DWPF would not appear to be a problem from a viscosity perspective. The measured viscosities for all three of the HM glasses are well above the upper limit and, thus, outside of the operating window for DWPF. Although no Blend sludge glasses were fabricated, viscosity predictions for these glasses suggest that viscosity values may be close to 100 poise, or the upper limit for DWPF operations.

There are several interesting trends observed in the data. Whether one uses the target, measured, or bias-corrected measured compositions to predict viscosities using the current model, the predicted viscosities are always higher than the measured viscosities for the glasses batched using Purex sludge. This may not be unexpected since some of the elements in CST and MST are not considered in the viscosity model. This overprediction does not occur for the glasses made using HM sludge. However, these viscosities are beyond DWPF's operating window. Further work may be required to include the additional elements introduced by CST into the viscosity model.

\section{Liquidus Temperature $\left(\mathbf{T}_{\mathbf{L}}\right)$}

The standard ASTM procedure for measuring liquidus temperature uses a gradient furnace. The equipment for determining liquidus temperature by this method is being installed and tested within SRTC in a clean laboratory. Due to the presence of depleted uranium in the glass samples (as well as the early stage of equipment setup), this method for liquidus determination was not available at SRTC for these analyses. A decision was therefore made to perform isothermal holds using reasonable quantities of the glass to bound the liquidus temperature.

XRD was selected as the method of detection for crystal formation in the glasses after an isothermal hold. It is estimated that the sensitivity of XRD (non-quantitative) is -0.7 to $1 \mathrm{wt} \%$ for a crystalline phase (in this case, Trevorite [16]). Therefore, for this type of measurement, absence of detection of a crystalline phase was evidence that the liquidus temperature is less than the temperature of that isothermal hold. On the other hand, detection of Trevorite (or any other primary crystalline phase) 
indicates that the liquidus temperature is higher than the temperature of the isothermal hold. The bounds on the liquidus temperatures for these CST glasses, estimated to the detection capabilities of $X R D$, are given in Table 3 . The model predictions for $T_{\mathbf{L}}$ based upon target, measured, and biascorrected compositions are also provided in this table. Given the fact that liquidus temperatures were only bounded, the $30 \mathrm{wt} \%$ loading of Purex may be near or at the edge of acceptability for liquidus.

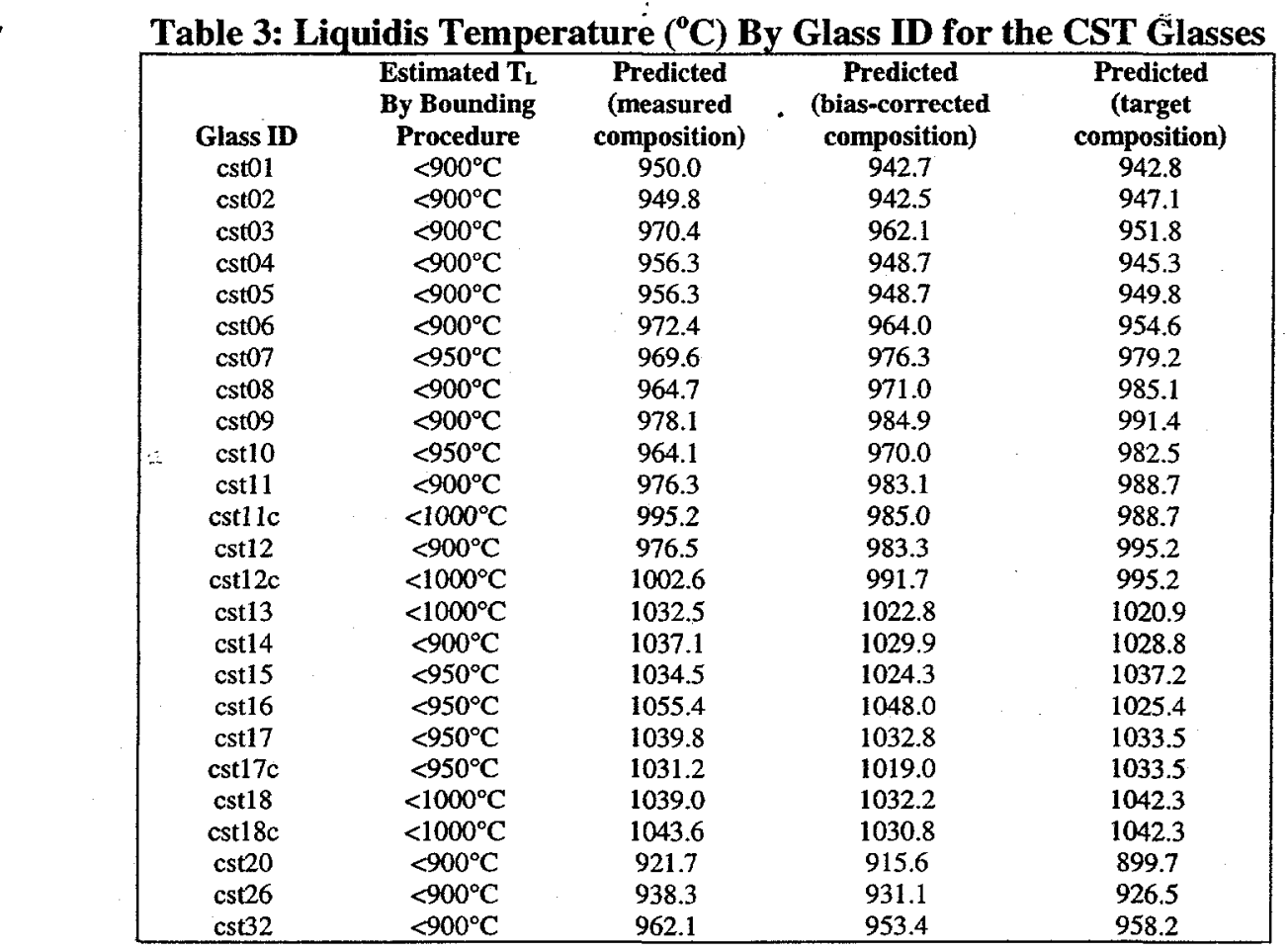

Figure 4 provides a comparison between the $T_{L}$ predictions of Table 12 and the corresponding bounding measurements. A 45-degree (diagonal) line is also shown for reference.

Figure 4: $T_{L}$ Measurements versus Property Predictions

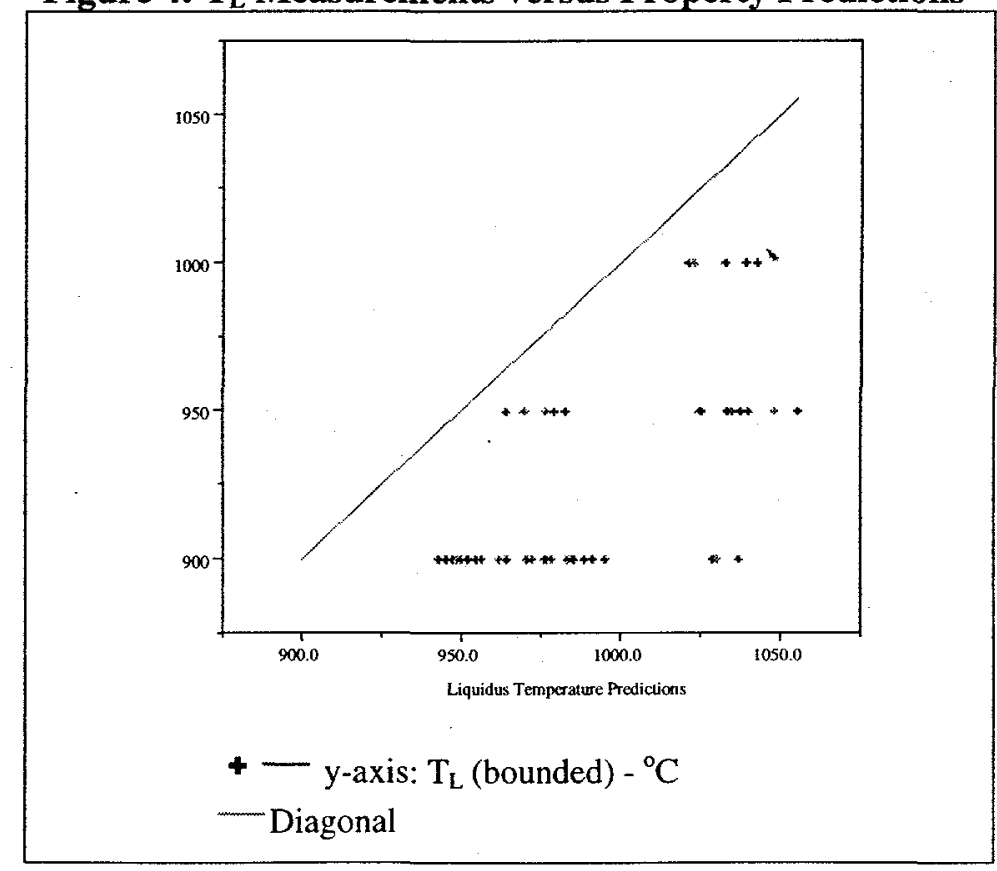


The bounded estimates of $T_{L}$ suggest that the liquidus temperatures of these glasses are within the DWPF operating window for this property. The model predictions versus the bounding estimates suggest that the model may be conservative for these glasses. Therefore, it may be necessary to modify the liquidus temperature model to include elements of CST and prevent unnecessarily conservative constraints on this property.

\section{Surface Crystallization}

For liquidus measurements, crystal formation only in the interior glass region is considered. Therefore, samples submitted for XRD analysis were bulk samples. However, crystals can form at the interface of the glass and the crucible and/or the glass and air. For completeness, the detection of these surface crystals on the top of the glass is provided in Table 4 as a function of temperature.

Table 4. Surface Crystals for the Six CST Glasses as a Function of Temperature

\begin{tabular}{|c|c|c|c|c|c|}
\hline \multirow{26}{*}{$\approx$} & & $1150^{\circ} \mathrm{C}$ & $1000^{\circ} \mathrm{C}$ & $950^{\circ} \mathrm{C}$ & $900^{\circ} \mathrm{C}$ \\
\hline & $\operatorname{cst} 01$ & No Test & No Test & No Test & none \\
\hline & $\operatorname{cst} 02$ & No Test & No Test & No Test & none \\
\hline & $\operatorname{cst} 03$ & No Test & No Test & No Test & none \\
\hline & $\operatorname{cst} 04$ & No Test & No Test & No Test & none \\
\hline & $\operatorname{cst} 05$ & No Test & No Test & No Test & none \\
\hline & cst06 & No Test & No Test & No Test & none \\
\hline & $\operatorname{cst} 07$ & none & none & crystals & crystals \\
\hline & $\operatorname{cst} 08$ & none & none & crystals & crystals \\
\hline & $\operatorname{cst} 09$ & none & crystals & crystals & crystals \\
\hline & $\operatorname{cst} 10$ & none & none & crystals & crystals \\
\hline & $\operatorname{cst} 11$ & none & none & crystals & crystals \\
\hline & cst1 lc & No Test & none & crystals & crystals \\
\hline & $\operatorname{cst12}$ & none & crystals & crystals & crystals \\
\hline & $\operatorname{cst} 12 c$ & No Test & crystals & crystals & crystals \\
\hline & $\operatorname{cstl} 3$ & none & crystals & crystals & crystals \\
\hline & $\operatorname{cst} 14$ & crystals & crystals & crystals & crystals \\
\hline & $\operatorname{cst} 15$ & crystals & crystals & crystals & crystals \\
\hline & $\operatorname{cst16}$ & none & crystals & crystals & crystals \\
\hline & $\operatorname{cst} 17$ & crystals & crystals & crystals & crystals \\
\hline & $\operatorname{cst17} \mathrm{c}$ & No Test & No Test & crystals & crystals \\
\hline & $\operatorname{cst} 18$ & crystals & crystals & crystals & crystals \\
\hline & $\operatorname{cst} 18 \mathrm{c}$ & No Test & crystals & crystals & crystals \\
\hline & $\operatorname{cst} 20$ & No Test & No Test & No Test & none \\
\hline & $\operatorname{cst} 26$ & No Test & No Test & No Test & none \\
\hline & $\operatorname{cst} 32$ & No Test & No Test & No Test & none \\
\hline
\end{tabular}

The crystals observed were located circumferentially and adjacent to the crucible - top glass surface. The chemical composition of the surface crystals was determined by EDS and is consistent with the Trevorite $\left(\mathrm{NiFe}_{2} \mathrm{O}_{4}\right)$ crystal structure. Trevorite has also been observed during previous studies on these types of systems. The chemical composition indicates that othor cations are substituted into the crystal structure in small amounts and these include $\mathrm{Ti}, \mathrm{Cr}$, and $\mathrm{Mn}$.

A different crystal type was also observed in several of the glasses for which SEM analyses were performed. In this case $\mathrm{Fe}$ and $\mathrm{Ti}$ are the two major elements of the crystal with $\mathrm{Ni}, \mathrm{Cr}$, and $\mathrm{Mn}$ present in smaller amounts. The amount of this type of crystal relative to the Trevorite was quite small. 


\section{Phase Separation}

The formation of separate amorphous phases in glass is referred to as amorphous phase separation or inhomogeneity. Crystal formation, as determined by liquidus temperature measurements, on the other band may indicate a "separation of phases," but reflects crystalline particles within the glass matrix. Amorphous phase separation is to be avoided since the models currently used to predict durability do not apply for glasses predicted to be phase separated. The property acceptance region, or PAR, limit for the homogeneity constraint in the Product Composition Control System (PCCS) is nominally a value of 211 [17]. The limit for the measurement acceptance region, or MAR, for this property will be even higher. In order to pass this constraint, the predicted homogeneity based upon the measured composition must be greater than the MAR value. The homogeneity values calculated using the targeted and measured chemical compositions are provided in Table 5.

\section{Table 5: Homogeneity Property Predictions}

\begin{tabular}{|c|c|c|c|}
\hline \multirow[b]{2}{*}{ Glass ID } & \multicolumn{3}{|c|}{$\begin{array}{c}\text { Homogeneity Property Prediction } \\
\text { based on } \\
\text { (Acceptability Requires a Value }>211 \text { ) }\end{array}$} \\
\hline & $\begin{array}{c}\text { Target } \\
\text { Composition }\end{array}$ & $\begin{array}{c}\text { Measured } \\
\text { Composition }\end{array}$ & $\begin{array}{l}\text { Bias-Corrected } \\
\text { Composition }\end{array}$ \\
\hline cst01 & 199.3 & 202.0 & 199.6 \\
\hline $\operatorname{cst} 02$ & 195.7 & 195.9 & 193.6 \\
\hline cst03 & 192.0 & 198.9 & 196.3 \\
\hline cst04 & 197.5 & 200.2 & 197.7 \\
\hline cst05 & 193.9 & 196.9 & 194.5 \\
\hline $\operatorname{cst} 06$ & 190.2 & 197.4 & 194.8 \\
\hline cst07 & 207.0 & 201.9 & 206.2 \\
\hline cst08 & 203.3 & 202.2 & 206.8 \\
\hline $\operatorname{cst} 09$ & 199.6 & 198.4 & 202.9 \\
\hline $\operatorname{cst10}$ & 205.2 & 203.5 & 208.1 \\
\hline $\operatorname{cst11}$ & 201.5 & 198.3 & 202.8 \\
\hline $\operatorname{cst1} 1 \mathrm{cc}$ & 201.5 & 203.0 & 199.2 \\
\hline cst12 & 197.8 & 198.9 & 203.3 \\
\hline $\operatorname{cst12c}$ & 197.8 & 197.6 & 194.0 \\
\hline cst13 & 214.6 & 219.4 & 222.2 \\
\hline cst14 & 211.0 & 220.9 & 222.3 \\
\hline cst15 & 207.3 & 212.9 & 216.0 \\
\hline $\operatorname{cst16}$ & 212.8 & 225.9 & 227.2 \\
\hline cst17 & 209.2 & 221.6 & 222.9 \\
\hline $\operatorname{cst1} 7 \mathrm{c}$ & 209.2 & 211.3 & 207.1 \\
\hline cst18 & 205.5 & 212.3 & 213.8 \\
\hline cst1 18c & 205.5 & 208.0 & 203.7 \\
\hline $\operatorname{cst} 20$ & 197.0 & 206.1 & 203.6 \\
\hline cst26 & 204.9 & 209.1 & 206.7 \\
\hline cst32 & 212.8 & 214.7 & 212.2 \\
\hline
\end{tabular}

Figure 5 provides a plot of the (common logarithm of the) normalized PCT response versus the homogeneity prediction based upon target, measured, and bias-corrected compositions. A vertical line on the $\mathbf{x}$-axis at 211 represents the PAR value for the homogeneity property constraint. The horizontal line at $\sim 1.23$ represents the common logarithm of the normalized PCT response of EA glass. The reference response for $\mathrm{EA}$ is $16.7 \mathrm{~g} / \mathrm{L}[17]$. 
Figure 5: Homogeneity Predictions versus Log ${ }_{10}$ (Normalized PCT Response)

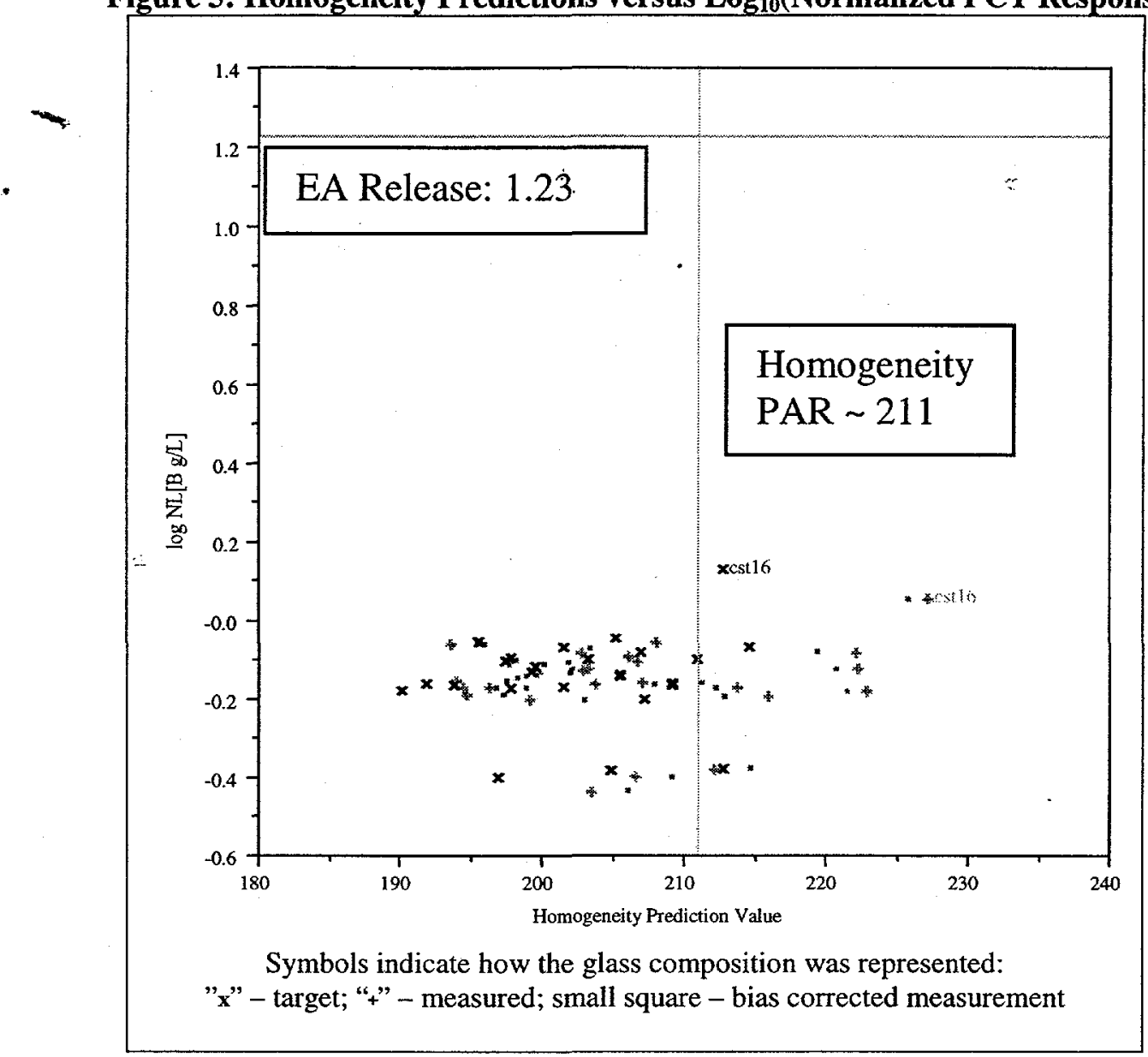

The PCT responses of the CST glasses made using Purex cover a reasonably wide range of homogeneity predictions while their PCT response all fall within the interval of $0.64 \mathrm{~g} / \mathrm{L}$ to $1.36 \mathrm{~g} / \mathrm{L}$ with cst16 included or $0.64 \mathrm{~g} / \mathrm{L}$ to $0.91 \mathrm{~g} / \mathrm{L}$ without cst16 (the main cluster of PCT responses, see Figures 1 and 2). The PCT responses for the three CST glasses made using HM sludge fall within the interval of $0.37 \mathrm{~g} / \mathrm{L}$ to $0.43 \mathrm{~g} / \mathrm{L}$.

The homogeneity constraint was developed for glasses that do not contain some of the elements found in CST and/or for glasses with components at concentrations not provided by the CST glasses. Therefore, the predictions of phase separation by this model may not be appropriate. It appears that this is the case for two reasons: (1) the measured durabilities compare very favorably to the EA durabilities, and (2) limited SEM analyses that were performed during this study did not exhibit phase separation. On the other hand, detection of phase separation is not straightforward. Absence of detection of phase separation by SEM does not ensure absence of phase separation. The scale and contrast may be such that other techniques such as SAXS or TEM are required to definitively identify phase separation. In addition, no acid etching or other techniques were used in sample preparation for the SEM analysis since this is outside the scope of this task. Finally, macroscopic phase separation was not investigated.

Although outside the scope of this study, kinetic effects (e.g., glasses subjected to centerline cooling conditions) should be investigated as part of the future work on the CST alternative, if it is selected as the ITP replacement. This investigation is needed since one cannot rule out that amorphous phase separation occurs in these glasses with centerline cooling, for example, and this could have a deleterious effect on the durability of the glass. 


\section{CONCLUSIONS}

This report is a modified version of WSRC-TR-99-00324, Revision 0. All data related to the composition of CST and to the proprietary frit (the glass formers) used during this study have been removed for this version. As a consequence of the need to remove confidential and proprietary information, this report also does not contain the tables of detailed target and measured glass

- compositions provided in WSRC-TR-99-00324. The report does, however, provide the full details of the glass property measurements generated as part of this study and relates these to glass composition

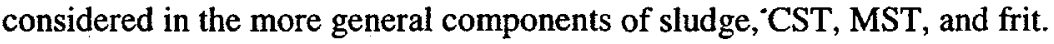

This report provides a summary of the results obtained for a limited variability study for glasses containing CST, MST, and either simulated Purex or HM sludge. Twenty-two glasses containing Purex sludge and three glasses containing HM sludge were fabricated and tested. The fabricated glasses were tested for durability using the 7-day PCT and characterized by measuring the viscosity at $1150^{\circ} \mathrm{C}$ and by determining an approximate, bounding liquidus temperature. The current models used by DWPF for predicting durability, viscosity, and liquidus temperature were applied to all 25 glasses. The goal of this work was to identify any major problems from a glass perspective, within the scope of this effort, which could potentially preclude the use of CST at DWPF.

The selection of Purex sludge for this study was based on the knowledge that this sludge type has historically been the most difficult sludge to incorporate into glass. Depleted uranium was introduced into the simulated Purex sludge to better represent the uranium content $(\sim 9$ wt\% oxide) of actual sludge.

One of the major elements of concern for this study was titanium, which the DWPF currently restricts to a value of less than $1 \mathrm{wt} \% \mathrm{TiO}_{2}$ in glass. The introduction of CST and MST in this study results in $\mathrm{TiO}_{2}$ levels in the glasses that significantly exceed the current limit. Furthermore, CST introduces $\mathrm{x}_{1}$, a proprietary component of CST with an unknown impact on glass quality and processing properties and higher levels of $\mathrm{x}_{2}$ (a second proprietary component of CST) than previously studied.

The "frit" (for this study, the glass formers were added as powders rather than a frit) composition was one of two optimized formulations selected from previous work at SRTC. This particular "frit" formulation is part of a current patent application.

As part of this study, product and property model predictions were made using targeted, measured, and bias-corrected measured compositions of the glasses. It was demonstrated that the results were essentially insensitive to the type of composition used in these models. This provides evidence that the glasses produced were close to the targeted compositions, and that the analytical measurements were of high quality.

Glass Durability. All 25 glasses were very durable as measured by the PCT. The PCT values clustered within the interval from 0.64 to $0.91 \mathrm{~g} / \mathrm{L}$ for boron for all of the Purex glasses except one and ranged from 0.37 to $0.43 \mathrm{~g} / \mathrm{L}$ for boron for the HM glasses. For comparison, the reference Environmental Assessment (EA) glass has a boron rate of $16.7 \mathrm{~g} / \mathrm{L}$. A remarkable finding from this study was the highly clustered nature of the results. The 22 Purex-loaded glasses clustered tightly in one region, whereas the HM glasses clustered at an even lower value for boron release.

Model Prediction of Durability. DWPF's Product Composition Control System (PCCS) durability model predicted values for boron release that were generally greater than the upper $95 \%$ prediction limit of the model. This type of behavior has been observed before for a range of glasses predicted to be very durable. The highly clustered nature of the results suggests that model revisions could be made to ensure predictability of the glasses. 
Homogeneity. The DWPF durability model was developed for glasses that are not phase separated (amorphous), and the use of this model is controlled, in part, through the application of a homogeneity discriminator or constraint. The majority of the CST glasses failed this homogeneity constraint (i.e., they are predicted to be phase separated) even though they demonstrated very good durabilities. Good dưfability does not ensure the lack of phase separation. However, the current DWPF homogeneity constraint was not developed for glasses within the compositional region defined for these 25 glasses.

- The results from this study reveal that the measured durabilities are not correlated to the values of this homogeneity constraint for these glasses. This is evident from the tightly clustered PCT results.

Liquidus. For this study, the liquidus temperature was bounded by performing 24-hour isothermal holds (as required) for the glass melts at $900^{\circ} \mathrm{C}, 950^{\circ} \mathrm{C}, 1000^{\circ} \mathrm{C}$, and $1050^{\circ} \mathrm{C}$. X-ray diffraction (XRD) was used to detect crystallization, in this case Trevorite. For the 22 wt\% Purex glasses, no crystals were detected in the bulk at $900^{\circ} \mathrm{C}$ or at the top surface of the glasses. For the $26 \mathrm{wt} \%$ Purex glasses, only two of the six glasses had bulk crystals after 24 hours at $900^{\circ} \mathrm{C}$, and crystallization was no longer evident after the 24 hour hold at $950^{\circ} \mathrm{C}$. For the $30 \mathrm{wt} \%$ Purex glasses, crystals were evident at higher temperatures but below the XRD detection limit at $1000^{\circ} \mathrm{C}$. Given the fact that liquidus temperatures were only bounded, the $30 \mathrm{wt} \%$ loading of Purex may be near or at the edge of acceptability for liquidus. - Surface crystallization was evident on top of the glass surface near the glass-crucible interface after some of the heat treatments. This crystallization was not considered as evidence in the determination of the approximate liquidus temperature. For HM glasses, no crystals were detected in the bulk or on the surface after 24 hours at $900^{\circ} \mathrm{C}$.

Viscosity. The melt viscosity for many of these glasses was measured and the results reported at $1150^{\circ} \mathrm{C}$ (nominal temperature of the glass within the DWPF melter). For the Purex containing glasses, all viscosities were well within the DWPF range of 20 to 100 poise. The viscosity model, in general, overpredicted the measured viscosities. This is not surprising given the fact that the model was not developed for glasses incorporating CST elements. On the other hand, the HM sludge-containing glasses had, as predicted, viscosities at $1150^{\circ} \mathrm{C}(\sim 160$ poise $)$ that were far above the 100 poise limit. Thus, the HM sludge-containing glasses fabricated for this study are not acceptable for processing in the DWPF. Although no Blend sludge glasses were fabricated, viscosity predictions for these glasses suggest that viscosity values may be close to 100 poise, or the upper limit for DWPF operations.

Limitations. All of the conclusions are provided based on the scope of the current work. One limitation of this scope, based upon schedule and budget, was the absence of any investigation of kinetic effects. Thus, one can not rule out that amorphous phase separation occurs with centerline cooling, for example, and this could have a deleterious effect on the durability of the glass. A second limitation was the restriction on independent variation of chemical constituents. In a major variability study, ranges are established for each element, and a statistically designed set of glasses identified which not only covers a larger region of compositional space, but also provides the potential for revealing (or confirming) relationships between the properties and the glass compositions. A third limitation was that only approximate and bounding measurements of the liquidus temperatures were made. A fourth limitation was that a thorough search (beyond scanning electron microscopy) for phase separation was not conducted. This type of investigation requires considerable efforts using transmission electron microscopy (TEM) and/or other high-resolution techniques. Finally, although the strategy was that HM and Purex containing glasses would cover the extremes, no Blend sludge (a combination of the HM and Purex sludges) glasses were fabricated to verify this. 


\section{REFERENCES}

[1] Elder, H. H., "Technical Task Request: DWPF Waste Qualification - CST Alternative Glass Variability Study," HLW-SDT-TTR-99-11.0, February 2, 1999.

[2] Harbour, J. R. and T. B. Edwards, "Technical Task and QA Plan: DWPEWaste QualificationCST in Glass," WSRC-RP-99-00195, Revision 0, February 17, 1999.

[3] Edwards, T. B., J. R. Harbour, R. J. Workmån, "Composition and Property Measurement for CST Phase 1 Glasses (U),"WSRC-TR-99-00245, July 27, 1999.

[4] Edwards, T. B., J. R. Harbour, R. J. Workman, "Composition and Property Measurement for CST Phase 2 Glasses (U)," WSRC-TR-99-00289, August 18, 1999.

[5] Edwards, T. B., J. R. Harbour, R. J. Workman, "Composition and Property Measurement for CST Phase 3 Glasses (U),"WSRC-TR-99-00291, August 18, 1999.

[6] Edwards, T. B., J. R. Harbour, R. J. Workman, "Composition and Property Measurement for CST Phase 4 Glasses (U)," WSRC-TR-99-00293, August 18, 1999.

[7] ASTM C1285-97, "Standard Test Methods for Determining Chemical Durability of Nuclear Waste Glasses: The Product Consistency Test (PCT)," 1997.

[8] Harbour, J. R. and T. B. Edwards, "Analytical Study Plan-CST: DWPF Waste QualificationCST in Glass," WSRC-RP-99-00316, Revision 0, April 14, 1999.

[9] Schumacher, R. F. and D. K. Peeler, "Establishment of Harrop, High-Temperature Viscometer," WSRC-RP-98-00737, Revision 0, September 1998.

[10] Schumacher, R. F., R. J. Workman, J. R. Harbour, and T. B. Edwards, "Measurements of DWPF Glass Viscosity - Interim Report," WSRC-RP-99-00350, Revision 0, May 5, 1999.

[11] Edwards, T. B., J. R. Harbour, R. J. Workman, "Composition and Property Measurement for PHA Phase 1 Glasses (U)," WSRC-TR-99-00262, August 4, 1999.

[12] Edwards, T. B., J. R. Harbour, R. J. Workman, "Composition and Property Measurement for PHA Phase 2 Glasses (U)," WSRC-TR-99-00290, August 18, 1999.

[13] Edwards, T. B., J. R. Harbour, R. J. Workman, "Composition and Property Measurement for PHA Phase 3 Glasses (U)," WSRC-TR-99-00292, August 18, 1999.

[14] Edwards, T. B., J. R. Harbour, R. J. Workman, "Composition and Property Measurement for CST Phase 4 Glasses (U)," WSRC-TR-99-00294, August 18, 1999.

[15] Jantzen, C. M., J. B. Pickett, K. G. Brown, T. B. Edwards, and D. C. Beam, "Process/Product Models for the Defense Waste Processing Facility (DWPF): Part I. Predicting Glass Durability from Composition Using a Thermodynamic Hydration Energy Reaction Model (THERMO) (U)," WSRC-TR-93-672, Rev. 1, September 28, 1995.

[16] Cicero, C. A., S. L. Marra, and M. K. Andrews, "Phase Stability Determinations of DWPF Waste Glasses (U)," WSRC-TR-93-227, Revision 0, 1993.

[17] Brown, K. G. and R. L. Postles, "SME Acceptability Determination for DWPF Process Control (U)," WSRC-TR-95-0364, Revision 3, February 21, 1996. 
WSRC-TR-99-00384

Revision 0

This page intentionally left blank. 


\section{Appendix:}

\section{Supplemental Tables and Exhibits}


Table A.1: Normalized PCTs for the CST Glasses

\begin{tabular}{|c|c|c|c|c|c|c|c|c|c|}
\hline Glass ID & Composition & $\begin{array}{c}\log N L \\
{[B(g / L)]}\end{array}$ & $\begin{array}{c}\log N L \\
{[\mathrm{Si}(\mathrm{g} / \mathrm{L})]}\end{array}$ & $\begin{array}{c}\log \mathrm{NL} \\
{[\mathrm{Na}(\mathrm{g} / \mathrm{L})]}\end{array}$ & $\begin{array}{c}\log N L \\
{[\mathrm{Li}(\mathrm{g} / \mathrm{L})]}\end{array}$ & B $(g / L)$ & Si $(g / L)$ & $\mathrm{Na}(\mathrm{g} / \mathrm{L})$ & $\mathrm{Li}(\mathrm{g} / \mathrm{L})$ \\
\hline EA & Phase 1 & 1.24851 & 0.61951 & 1.15692 & 0.99969 & 17.72 & 4.16 & 14.35 & 9.99 \\
\hline EA - & Phase 2 & 1.27261 & 0.61353 & 1.17131 & 1.02046 & 18.73 & 4.11 & 14.84 & 10.48 \\
\hline EA & Phases 3-4 & 1.28207 & 0.63353 & 1.18838 & 1.04022 & 19.15 & 4.30 & 15.43 & 10.97 \\
\hline ARM & Phase 1 & -0.22197 & -0.50764 & -0.22580 & -0.16767 & 0.60 & 0.31 & 0.59 & 0.68 \\
\hline ARM & Phase 2 & -0.27166 & -0.55545 & -0.26983 & -0.20863 & 0.53 & 0.28 & 0.54 & 0.62 \\
\hline ARM & Phases 3-4 & -0.29085 & -0.54854 & -0.27396 & -0.21652 & 0.51 & 0.28 & 0.53 & 0.61 \\
\hline $\operatorname{cst01}$ & measured & -0.12435 & -0.31918 & -0.23985 & -0.05247 & 0.75 & 0.48 & 0.58 & 0.89 \\
\hline $\operatorname{cst} 01$ & measured bc & -0.12324 & -0.32239 & -0.23089 & -0.04420 & 0.75 & 0.48 & 0.59 & 0.90 \\
\hline $\operatorname{cst01}$ & target & -0.12196 & -0.32523 & -0.23001 & -0.04823 & 0.76 & 0.47 & 0.59 & 0.89 \\
\hline $\operatorname{cst} 02$ & measured & -0.05198 & -0.27299 & -0.20880 & -0.00126 & 0.89 & 0.53 & 0.62 & 1.00 \\
\hline $\operatorname{cst02}$ & measured bc & -0.05088 & -0.27619 & -0.19984 & 0.00702 & 0.89 & 0.53 & 0.63 & 1.02 \\
\hline cst02 & target & -0.04745 & -0.28025 & -0.18768 & -0.00051 & 0.90 & 0.52 & 0.65 & 1.00 \\
\hline $\operatorname{cst} 03$ & measured & -0.16395 & -0.33018 & -0.32645 & -0.04703 & 0.69 & 0.47 & 0.47 & 0.90 \\
\hline $\operatorname{cst03}$ & measured bc & -0.16277 & -0.33334 & -0.31750 & -0.03876 & 0.69 & 0.46 & 0.48 & 0.91 \\
\hline cst03 & target & -0.15573 & -0.33109 & -0.32570 & -0.04384 & 0.70 & 0.47 & 0.47 & 0.90 \\
\hline $\operatorname{cst04}$ & measured & -0.09945 & -0.29776 & -0.23100 & -0.04302 & 0.80 & 0.50 & 0.59 & 0.91 \\
\hline cst04 & measured bc & -0.09833 & -0.30113 & -0.22205 & -0.03474 & 0.80 & 0.50 & 0.60 & 0.92 \\
\hline $\operatorname{cst04}$ & target & -0.09727 & -0.30844 & -0.21457 & -0.04103 & 0.80 & 0.49 & 0.61 & 0.91 \\
\hline $\operatorname{cst05}$ & measured & -0.16447 & -0.33605 & -0.29999 & -0.05928 & 0.68 & 0.46 & 0.50 & 0.87 \\
\hline cst05 & measured bc & -0.16337 & -0.33932 & -0.29103 & -0.05101 & 0.69 & 0.46 & 0.51 & 0.89 \\
\hline $\operatorname{cst05}$ & target & -0.15736 & -0.34069 & -0.28588 & -0.05478 & 0.70 & 0.46 & 0.52 & 0.88 \\
\hline cst06 & measured & -0.18098 & -0.35471 & -0.32769 & -0.06372 & 0.66 & 0.44 & 0.47 & 0.86 \\
\hline cst06 & measured bc & -0.17979 & -0.35784 & -0.31876 & -0.05544 & 0.66 & 0.44 & 0.48 & 0.88 \\
\hline $\operatorname{cst} 06$ & target & -0.17339 & -0.35674 & -0.32151 & -0.06142 & 0.67 & 0.44 & 0.48 & 0.87 \\
\hline cst07 & measured & -0.09806 & -0.28825 & -0.20747 & 0.01814 & 0.80 & 0.51 & 0.62 & 1.04 \\
\hline cst07 & measured bc & -0.08139 & -0.29436 & -0.19868 & -0.00506 & 0.83 & 0.51 & 0.63 & 0.99 \\
\hline $\operatorname{cst} 07$ & target & -0.07279 & -0.29695 & -0.19016 & -0.04240 & 0.85 & 0.50 & 0.65 & 0.91 \\
\hline cst08 & measured & -0.11510 & -0.31487 & -0.22302 & 0.02146 & 0.77 & 0.48 & 0.60 & 1.05 \\
\hline cst08 & measured bc & -0.09877 & -0.32185 & -0.21417 & -0.00186 & 0.80 & 0.48 & 0.61 & 1.00 \\
\hline $\operatorname{cst08}$ & target & -0.09161 & -0.29904 & -0.21814 & -0.00820 & 0.81 & 0.50 & 0.61 & 0.98 \\
\hline $\operatorname{cst} 09$ & measured & -0.13588 & -0.33051 & -0.26031 & -0.00193 & 0.73 & 0.47 & 0.55 & 1.00 \\
\hline cst09 & measured bc & -0.11967 & -0.33732 & -0.25139 & -0.02512 & 0.76 & 0.46 & 0.56 & 0.94 \\
\hline $\operatorname{cst09}$ & target & -0.10825 & -0.32548 & -0.25227 & -0.03069 & 0.78 & 0.47 & 0.56 & 0.93 \\
\hline $\operatorname{cst10}$ & measured & -0.06250 & -0.28553 & -0.19071 & 0.03183 & 0.87 & 0.52 & 0.64 & 1.08 \\
\hline cst10 & measured $b c$ & -0.04671 & -0.29302 & -0.18215 & 0.00860 & 0.90 & 0.51 & 0.66 & 1.02 \\
\hline $\operatorname{cst} 10$ & target & -0.03883 & -0.27466 & -0.18092 & 0.00248 & 0.91 & 0.53 & 0.66 & 1.01 \\
\hline $\operatorname{cst11}$ & - measured & -0.09192 & -0.29540 & -0.21390 & 0.02895 & 0.81 & 0.51 & 0.61 & 1.07 \\
\hline $\operatorname{cst1} 1$ & measured $b c$ & -0.07563 & -0.30263 & -0.20524 & 0.00578 & 0.84 & 0.50 & 0.62 & 1.01 \\
\hline $\operatorname{cst11}$ & target & -0.06107 & -0.29732 & -0.20399 & 0.00404 & 0.87 & 0.50 & 0.63 & 1.01 \\
\hline $\operatorname{cst} 11 \mathrm{c}$ & measured & -0.19354 & -0.34311 & -0.27338 & -0.07213 & 0.64 & 0.45 & 0.53 & 0.85 \\
\hline cst11c & measured bc & -0.19442 & -0.34671 & -0.26192 & -0.05623 & 0.64 & 0.45 & 0.55 & 0.88 \\
\hline cst11c & target & -0.16126 & -0.35284 & -0.26397 & -0.06522 & 0.69 & 0.44 & 0.54 & 0.86 \\
\hline cst12 & measured & -0.12996 & -0.35011 & -0.26585 & -0.01164 & 0.74 & 0.45 & 0.54 & 0.97 \\
\hline $\operatorname{cst} 12$ & measured bc & -0.11382 & -0.35677 & -0.25728 & -0.03529 & 0.77 & 0.44 & 0.55 & 0.92 \\
\hline cst12 & target & -0.08825 & -0.33647 & -0.24300 & -0.02751 & 0.82 & 0.46 & 0.57 & 0.94 \\
\hline $\operatorname{cst12c}$ & measured & -0.14512 & -0.35323 & -0.28823 & -0.06484 & 0.72 & 0.44 & 0.51 & 0.86 \\
\hline $\operatorname{cst} 12 c$ & measured bc & -0.14556 & -0.35759 & -0.27677 & -0.04894 & 0.72 & 0.44 & 0.53 & 0.89 \\
\hline $\operatorname{cst} 12 \mathrm{c}$ & target & -0.16904 & -0.36273 & -0.28391 & -0.06369 & 0.68 & 0.43 & 0.52 & 0.86 \\
\hline $\operatorname{cst} 13$ & meas $b c$ & -0.07226 & -0.34836 & -0.19173 & -0.01661 & 0.85 & 0.45 & 0.64 & 0.96 \\
\hline $\operatorname{cst} 13$ & measured & -0.07181 & -0.33674 & -0.17484 & -0.02113 & 0.85 & 0.46 & 0.67 & 0.95 \\
\hline $\operatorname{cst1} 3$ & target & -0.06173 & -0.33596 & -0.18701 & -0.00265 & 0.87 & 0.46 & 0.65 & 0.99 \\
\hline $\operatorname{cst14}$ & meas bc & -0.11606 & -0.36994 & -0.24289 & -0.04764 & 0.77 & 0.43 & 0.57 & 0.90 \\
\hline $\operatorname{cst} 14$ & measured & -0.11570 & -0.36278 & -0.22599 & -0.05217 & 0.77 & 0.43 & 0.59 & 0.89 \\
\hline $\operatorname{cst14}$ & target & -0.09154 & -0.35151 & -0.21756 & -0.05111 & 0.81 & 0.45 & 0.61 & 0.89 \\
\hline cst15 & meas bc & -0.18735 & -0.39592 & -0.30843 & -0.07717 & 0.65 & 0.40 & 0.49 & 0.84 \\
\hline $\operatorname{cst} 15$ & measured & -0.18701 & -0.38303 & -0.29153 & -0.08164 & 0.65 & 0.41 & 0.51 & 0.83 \\
\hline $\operatorname{cst1} 5$ & target & -0.19305 & -0.37128 & -0.28438 & -0.06345 & 0.64 & 0.43 & 0.52 & 0.86 \\
\hline cst16 & meas bc & 0.06195 & -0.27895 & -0.05658 & 0.06500 & 1.15 & 0.53 & 0.88 & 1.16 \\
\hline cst16 & measured & 0.06229 & -0.27225 & -0.03969 & 0.06046 & 1.15 & 0.53 & 0.91 & 1.15 \\
\hline $\operatorname{cst16}$ & target & 0.13234 & -0.27891 & 0.01236 & 0.05841 & 1.36 & 0.53 & 1.03 & 1.14 \\
\hline $\operatorname{cst} 17$ & meas bc & -0.17251 & -0.38788 & -0.29107 & -0.07314 & 0.67 & 0.41 & 0.51 & 0.85 \\
\hline $\operatorname{cst17}$ & measured & -0.17219 & -0.38120 & -0.27416 & -0.07761 & 0.67 & 0.42 & 0.53 & 0.84 \\
\hline $\operatorname{cst} 17$ & target & -0.16037 & -0.35911 & -0.28468 & -0.05767 & 0.69 & 0.44 & 0.52 & 0.88 \\
\hline
\end{tabular}


WSRC-TR-99-00384

Revision 0

Table A.1: Normalized PCTs for the CST Glasses

(continued)

\begin{tabular}{|c|c|c|c|c|c|c|c|c|c|}
\hline Glass ID & Composition & $\begin{array}{c}\log N L \\
{[B(g / L)]}\end{array}$ & $\begin{array}{c}\log N L \\
{[S i(g / L)]}\end{array}$ & $\begin{array}{c}\log \mathrm{NL} \\
{[\mathrm{Na}(\mathrm{g} / \mathrm{L})]}\end{array}$ & $\begin{array}{c}\log N \mathrm{~L} \\
{[\mathrm{Li}(\mathrm{g} / \mathrm{L})]}\end{array}$ & $B(g / L)$ & Si $(g / L)$ & $\mathrm{Na}(g / L)$ & $\mathrm{Li}(g / L)$ \\
\hline $\operatorname{cst17} c^{-m}$ & measured & -0.14992 & -0.36499 & -0.25063 & -0.06857 & 0.71 & 0.43 & 0.56 & 0.85 \\
\hline $\operatorname{cst} 17 \mathrm{c}$ & measured bc & -0.15036 & -0.36882 & -0.23917 & -0.05267 & 0.71 & 0.43 & 0.58 & 0.89 \\
\hline cst17c & target & -0.15246 & -0.36126 & -0.23916 & -0.05398 & 0.70 & $0.44 \ldots$ & 0.58 & 0.88 \\
\hline cst 18 & meas bc & -0.16291 & -0.39588 & -0.26187 & -0.06008 & 0.69 & 0.40 & 0.55 & 0.87 \\
\hline cst18 & measured & -0.16255 & -0.38899 & -0.24497 & -0.06458 & 0.69 & 0.41 & 0.57 & 0.86 \\
\hline cst18 & target & -0.13228 & -0.37802 & -0.22898 & -0.04760 & 0.74 & 0.42 & 0.59 & 0.90 \\
\hline $\operatorname{cst} 18 \mathrm{c}$ & measured & -0.15241 & -0.37899 & -0.25763 & -0.07002 & 0.70 & 0.42 & 0.55 & 0.85 \\
\hline cst18c & measured bc & -0.15283 & -0.38270 & -0.24617 & -0.05412 & 0.70 & 0.41 & 0.57 & 0.88 \\
\hline cst $18 \mathrm{c}$ & target & -0.13827 & -0.37643 & -0.24260 & -0.05832 & 0.73 & 0.42 & 0.57 & 0.87 \\
\hline cst20 & measured & -0.42765 & -0.43450 & -0.64465 & -0.17087 & 0.37 & 0.37 & 0.23 & 0.67 \\
\hline cst20 & measured bc & -0.42800 & -0.43724 & -0.63319 & -0.15496 & 0.37 & 0.37 & 0.23 & 0.70 \\
\hline cst20 & target & -0.39386 & -0.44470 & -0.62129 & -0.17006 & 0.40 & 0.36 & 0.24 & 0.68 \\
\hline $\operatorname{cst} 26$ & measured & -0.38824 & -0.42580 & -0.60692 & -0.15319 & 0.41 & 0.38 & 0.25 & 0.70 \\
\hline cst26 & measured bc & -0.38859 & -0.42924 & -0.59545 & -0.13728 & 0.41 & 0.37 & 0.25 & 0.73 \\
\hline cst26 & target & -0.37506 & -0.42698 & -0.59613 & -0.14900 & 0.42 & 0.37 & 0.25 & 0.71 \\
\hline $\operatorname{cst} 32$ & measured & -0.36958 & -0.44364 & -0.61695 & -0.14119 & 0.43 & 0.36 & 0.24 & 0.72 \\
\hline $\operatorname{cst} 32$ & measured bc & -0.36998 & -0.44728 & -0.60548 & -0.12528 & 0.43 & 0.36 & 0.25 & 0.75 \\
\hline $\operatorname{cst} 32$ & target & -0.37278 & -0.44366 & -0.60790 & -0.13186 & 0.42 & 0.36 & 0.25 & 0.74 \\
\hline
\end{tabular}


Exhibit A.1: Durability Predictions Versus Measurements

$\log N L(B)(g / L)$ By del Gp

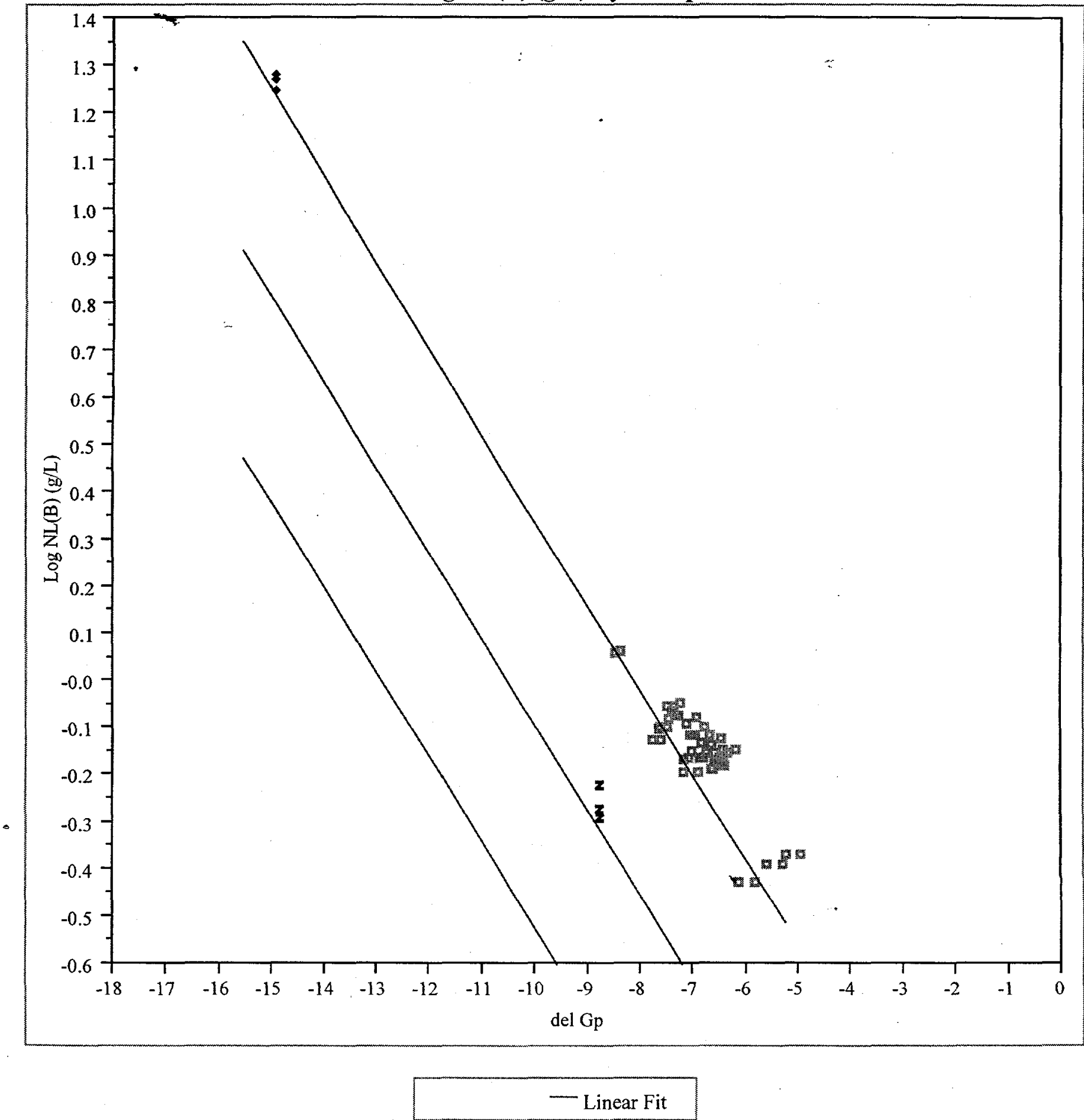

PCTs normalized and del $\mathrm{G}_{\mathrm{p}}$ determined from measured and meaured bias-corrected compositions. 


\section{Exhibit A.1: Durability Predictions Versus Measurements (continued)}

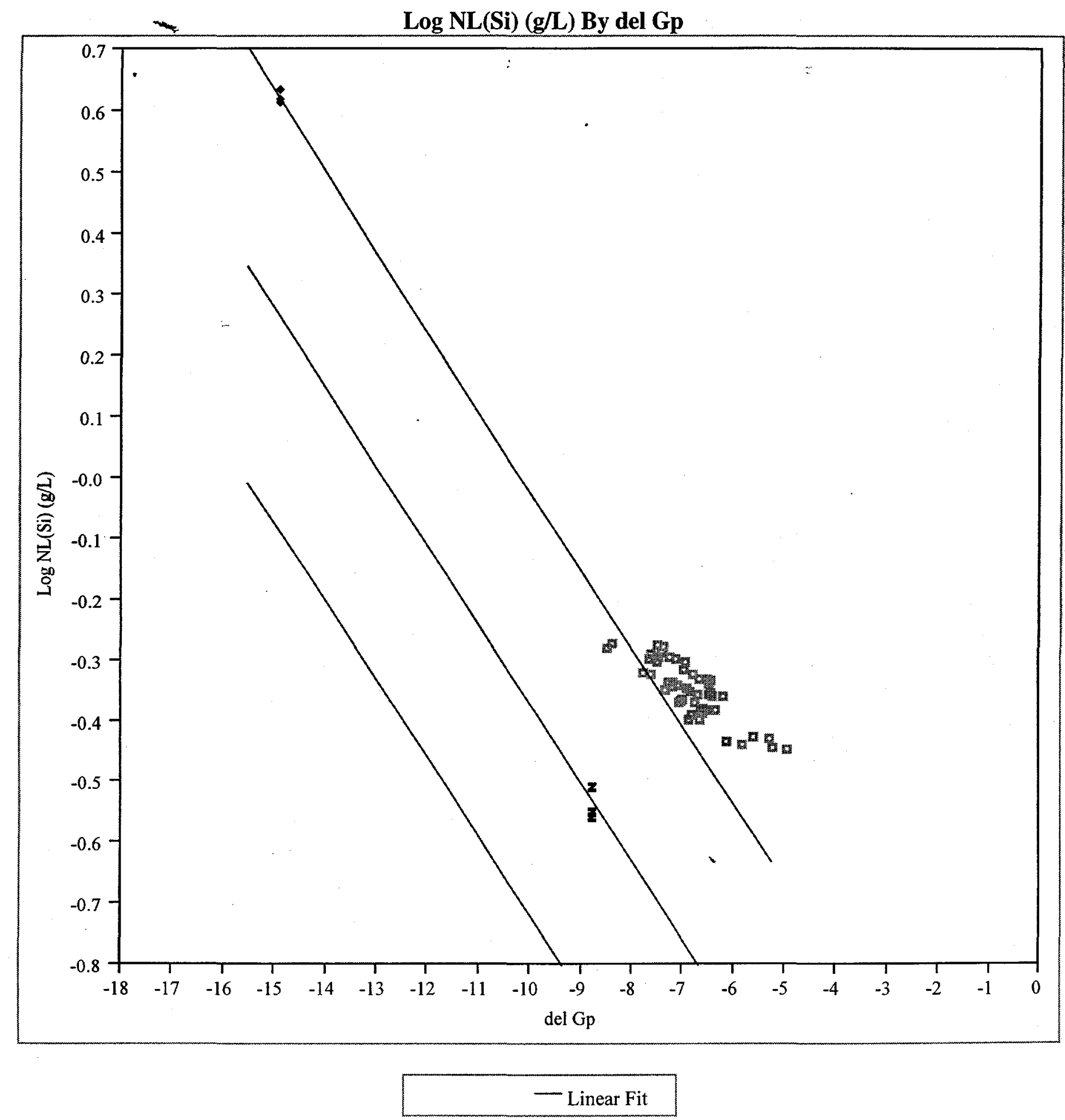

PCTs normalized and del $\mathrm{G}_{\mathrm{p}}$ determined from measured and meaured bias-corrected compositions. 
Exhibit A.1: Durability Predictions Versus Measurements (continued)

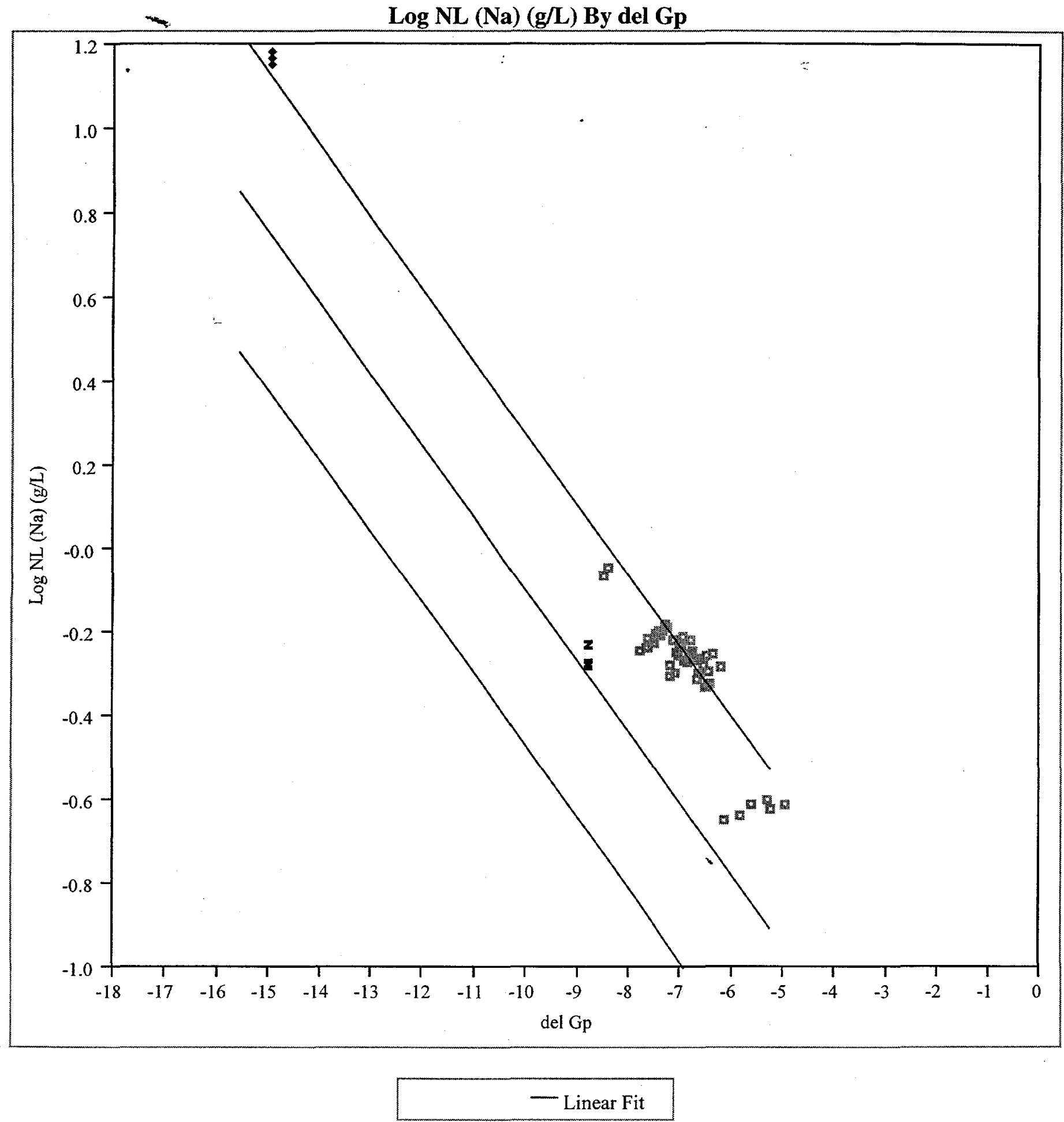

PCTs normalized and del $\mathrm{G}_{\mathrm{p}}$ determined from measured and meaured bias-corrected compositions. 
Exhibit A.1: Durability Predictions Versus Measurements

(continued)

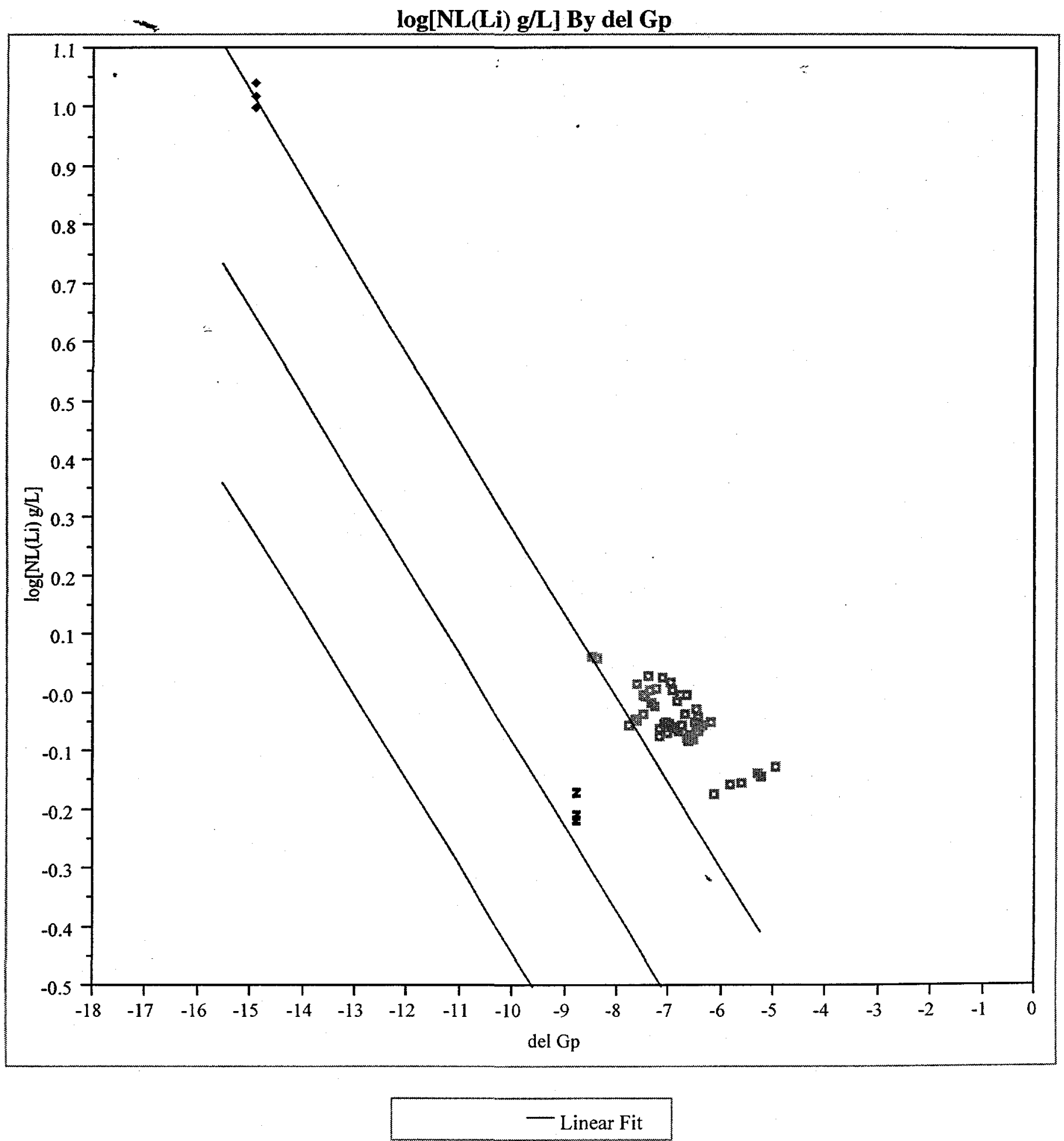

PCTs normalized and del $G_{p}$ determined from measured and meaured bias-corrected compositions. 
Exhibit A.1: Durability Predictions Versus Measurements (continued)

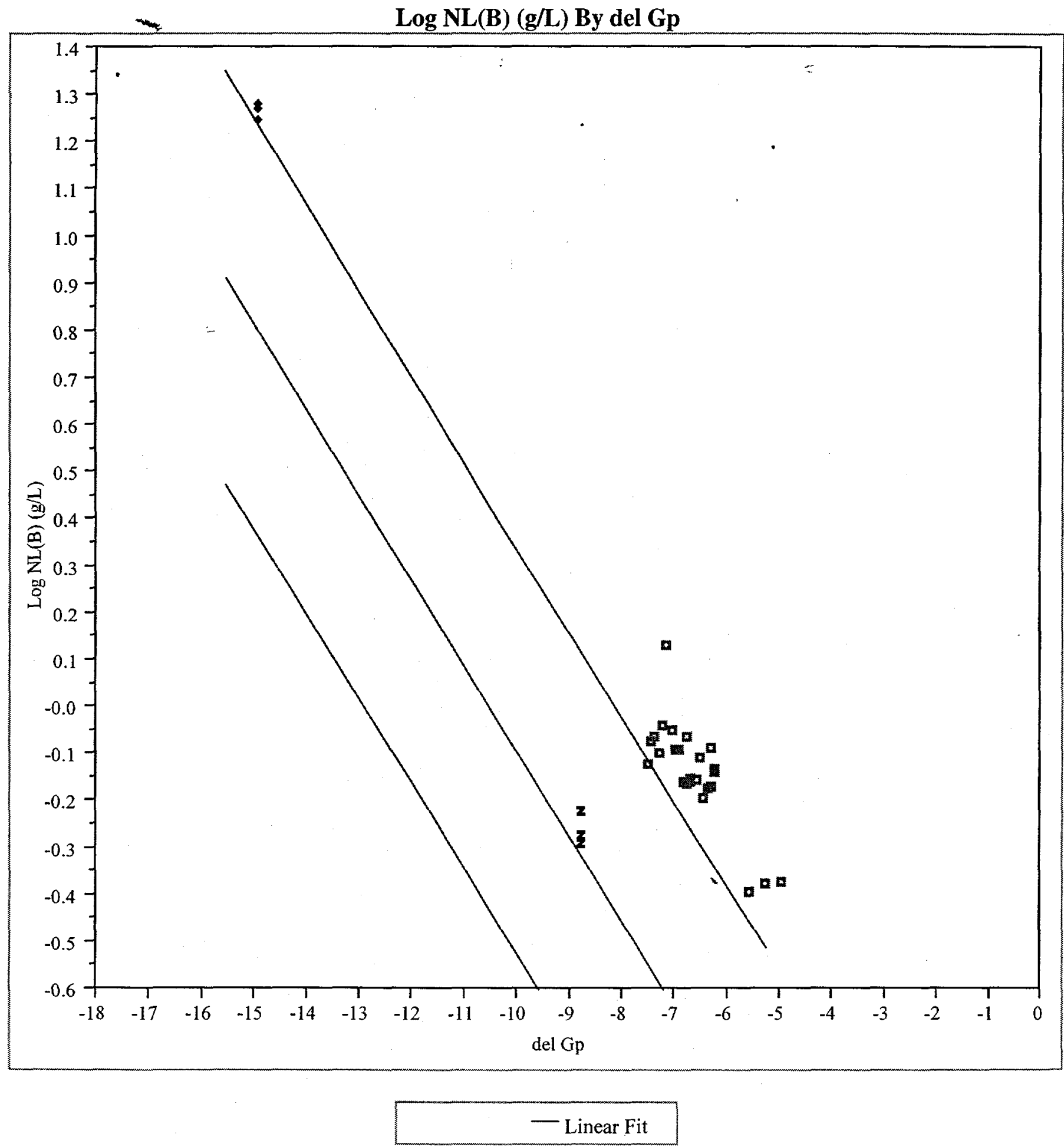

PCTs normalized and del $G_{p}$ determined from target compositions. 
Exhibit A.1: Durability Predictions Versus Measurements (continued)

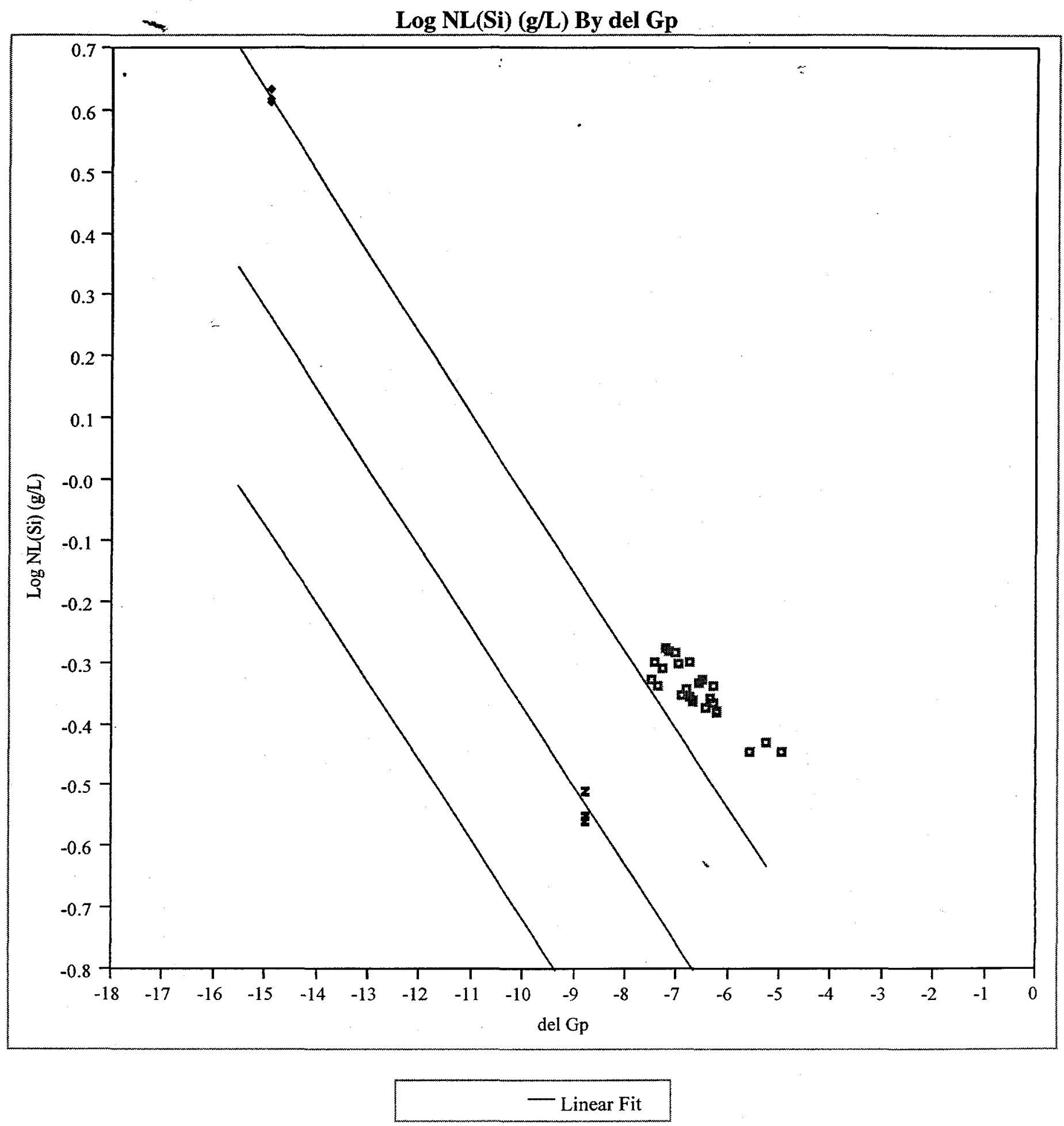

PCTs normalized and del $\mathrm{G}_{\mathrm{p}}$ determined from target compositions. 
Exhibit A.1: Durability Predictions Versus Measurements (continued)

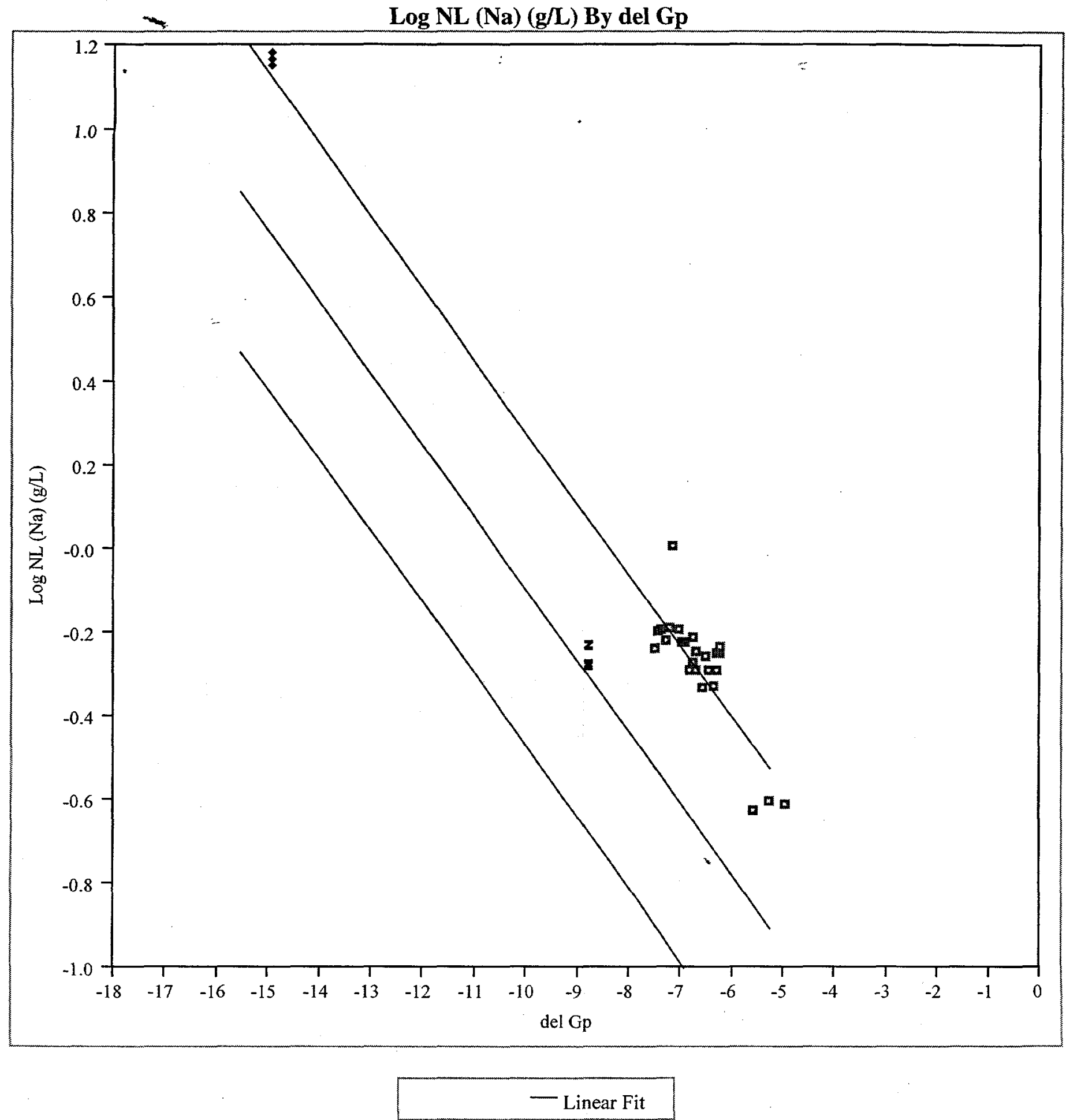

PCTs normalized and del $\mathrm{G}_{\mathrm{p}}$ determined from target compositions. 
Exhibit A.1: Durability Predictions Versus Measurements

(continued)

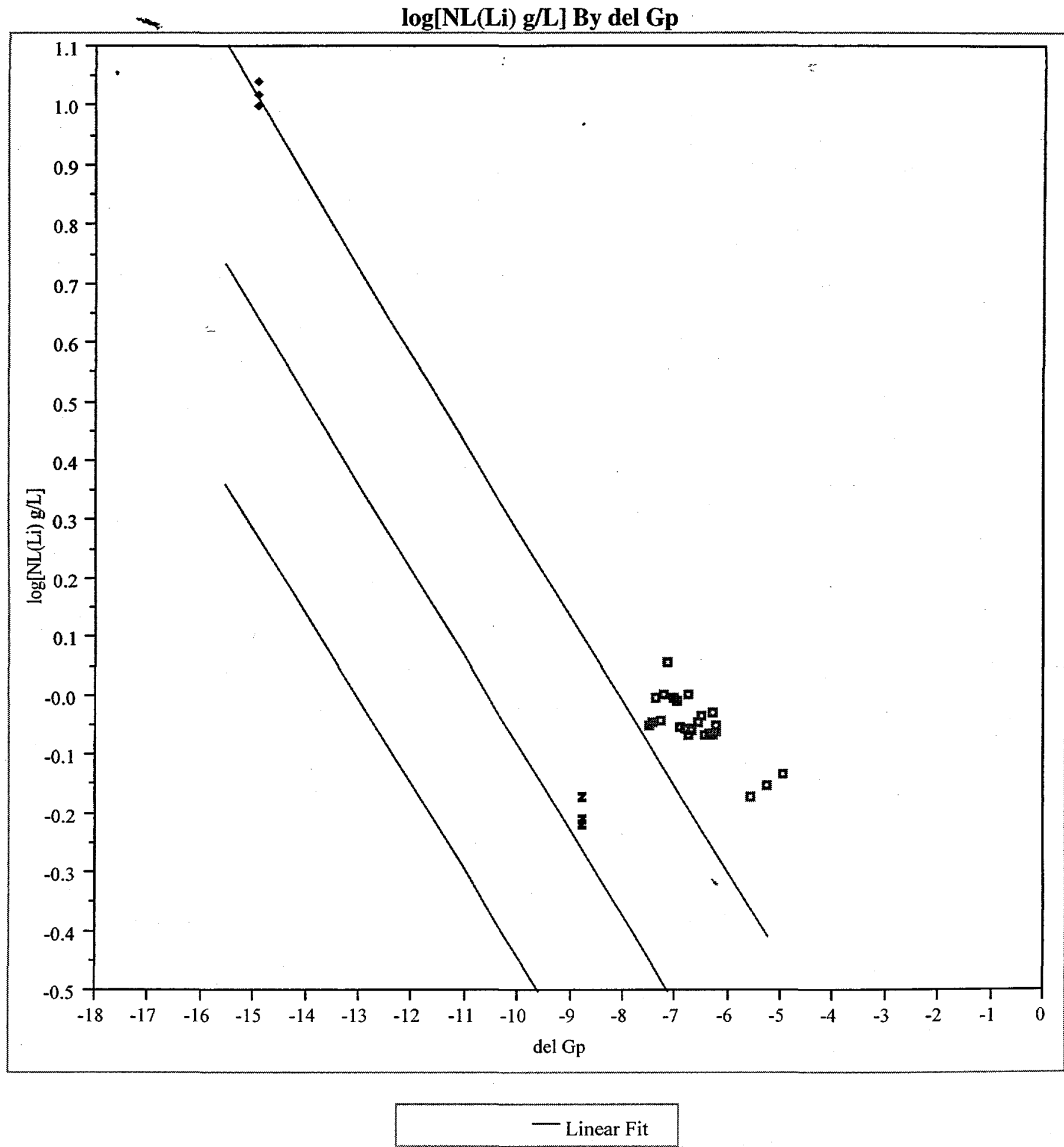

PCTs normalized and del $G_{p}$ determined from target compositions. 
WSRC-TR-99-00384

Revision 0

This page intentionally left blank. 
WSRC-TR-99-00384

Revision 0

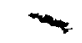

This page intentionally left blank. 


\section{Distribution}

K. G. Brown, 704-1T

J. T. Carter, 704-3N

T. B. Edwards, $773-42 \mathrm{~A}$

S. D. Fink, 773-A

J. R. Harbour, 773-43A

E. W. Holtzscheiter, 773-A

R. T. Jones, 704-3N

K. J. Rueter, 704-3N

W. L. Tamosaitis, 773-A

R. C. Tuckfield, 773-43A

R. J. Workman, 773-A

TIM (4 copies), 703-43A 